\title{
Assessing the genetic diversity of cowpea [Vigna unguiculata (L.) Walp.] germplasm collections using phenotypic traits and SNP markers
}

\section{Nelia Nkhoma}

University of KwaZulu-Natal School of Agricultural Earth and Environmental Sciences

Hussein Shimelis

University of KwaZulu-Natal School of Agricultural Earth and Environmental Sciences

Mark Laing

University of KwaZulu-Natal School of Agricultural Earth and Environmental Sciences

Admire Shayanowako

University of KwaZulu-Natal School of Agricultural Earth and Environmental Sciences

Isack Mathew ( $\nabla$ isackmathew@gmail.com )

University of KwaZulu-Natal https://orcid.org/0000-0001-7358-4690

Research article

Keywords: cowpea, genotypic diversity, phenotypic traits, SNP makers, population structure, yield components, Zambia

Posted Date: August 13th, 2020

DOl: https://doi.org/10.21203/rs.3.rs-26693/v2

License: (c) (1) This work is licensed under a Creative Commons Attribution 4.0 International License.

Read Full License

Version of Record: A version of this preprint was published at BMC Genetics on September 18th, 2020.

See the published version at https://doi.org/10.1186/s12863-020-00914-7. 


\title{
Assessing the genetic diversity of cowpea [Vigna unguiculata (L.) Walp.] germplasm collections using phenotypic traits and SNP markers
}

\author{
Nelia Nkhoma ${ }^{1,2}$, Hussein Shimelis ${ }^{1}$, Mark D. Laing ${ }^{1}$, Admire Shayanowako ${ }^{1}$, Isack Mathew ${ }^{1, *}$ \\ ${ }^{1}$ African Centre for Crop Improvement, University of KwaZulu-Natal, P/Bag X01, Scottsville 3209, \\ Pietermaritzburg, South Africa \\ ${ }^{2}$ Seed Control and Certification Institute, P. O. Box 350199, Chilanga, Lusaka, Zambia \\ nellyphiri47@gmail.com; shimelish@ukzn.ac.za; laing@ukzn.ac.za; shayanowako@googlemail.com \\ *Corresponding author: isackmathew@gmail.com
}

\begin{abstract}
Background: Productivity of cowpea [Vigna unguiculata (L.) Walp] in sub-Sahara Africa is curtailed by a lack of farmer-preferred and improved cultivars and modern production technologies. The objectives of the study were to determine the extent of genetic diversity present among a collection of cowpea accessions from Zambia and Malawi using phenotypic traits and single nucleotide polymorphism (SNP) markers and, to select distinct and complementary parental lines for cultivar development. One hundred cowpea genotypes were evaluated for agronomic traits in two selected sites in Zambia, using a 10×10 alpha lattice design with two replications. Ninety-four of the test genotypes were profiled with $14,116 \mathrm{SNP}$ markers.
\end{abstract}

Results: Number of pods plant ${ }^{-1}$ (NPP), pod length (PDL), and number of seeds $\operatorname{pod}^{-1}$ (NSP), were significantly $(p<0.05)$ affected by genotype $\times$ environment interaction effects. Genotypes such as CP411, CP421, CP645, CP732, Chimponongo, and MS1-8-1-4 exhibited higher grain yield of > $1200 \mathrm{~kg} / \mathrm{ha}$ with excellent performance in yield components such as NSP, PDL, HSW and GYD. Grain yield had significant $(\mathrm{p}<0.05)$ associations with NPP $(\mathrm{r}=0.50)$, NSP $(\mathrm{r}=0.46)$ and PDL ( $\mathrm{r}=0.42)$ useful for simultaneous selection for yield improvement in cowpea. The SNP markers revealed gene diversity and polymorphic information content of 0.22 and 0.17 , respectively, showing that the tested cowpea accessions were genetically diverse. Test genotypes were classified into four genetic groups irrespective of source of collection allowing selection and subsequent crosses to develop breeding populations for cultivar development. Conclusions: Genotypes Bubebe, CP411, CP421, CP645, Chimponogo and MS1-8-1-4 were identified to be the most genetically divergent and high yielding making them ideal parental lines for breeding. This study provided a baseline information and identified promising cowpea genetic resources for effective breeding and systematic conservation. 
Key words: cowpea, genotypic diversity, phenotypic traits, SNP makers, population structure, yield components, Zambia

\section{Background}

Cowpea [Vigna unguiculata (L.) Walp., $2 \mathrm{n}=2 \mathrm{x}=22$ ] is a relatively low cost source of plantderived protein, amino acids and essential nutrients globally. It is the main food staple supporting millions of people in sub-Sahara Africa (SSA) $[1 ; 2]$. The grain protein content of cowpea is about $250 \mathrm{mg} / \mathrm{g}$ [3], which is comparable to that of soybeans [2]. In addition, cowpea grain contains essential nutrients such as iron $(53.2 \mathrm{mg} / \mathrm{kg})$, zinc $(38.1 \mathrm{mg} / \mathrm{kg})$, calcium $(826$ $\mathrm{mg} / \mathrm{kg}$ ) and magnesium (1915 mg/kg) [3]. Young and succulent leaves and pods of cowpea are used as cooked vegetable, while the grains are ground and processed into powder for making thick porridge, gravy or sometimes consumed as a boiled delicacy [4].

Cowpea is a key companion crop in mixed cropping systems useful to supressing weed infestation, enhancing soil fertility and reducing water evaporation [5]. Cowpea forms symbiosis with the root nodule bacterium, Rhizobium, and fixes 70 to $350 \mathrm{~kg} / \mathrm{ha}$ of atmospheric nitrogen and some 40 to $80 \mathrm{~kg}$ of this is deposited into soils as a natural source of mineral nitrogen contributing to soil health [5]. Cowpea thrives under low soil fertility and dry-land growing conditions making it one of the most resilient legume crops suitable for the low input and water-limited production systems in SSA.

Global production of cowpea is estimated to be 6.5 million tons per annum on 14.5 million hectares of land [6]. The leading world producers of cowpea are Nigeria and Niger with five and three million hectares of production areas, respectively [7]. Cowpea is widely cultivated by small-scale farmers in southern African countries such as in Zambia, Zimbabwe, Malawi, Namibia, Mozambique and Botswana [8; 9]. The mean grain yields of cowpea in SSA is between 100 to $599 \mathrm{~kg} / \mathrm{ha}$ which is far less than the potential yield of the crop reaching up to 3 t/ha elsewhere [8; 10]. The yield gap is attributable to a lack of improved and high yielding cultivars, poor agronomic practices and an array of abiotic and biotic production constraints. Therefore, there is need to develop best performing, locally adapted and farmer-preferred cowpea varieties for sustainable production in the region.

The southern African countries including Namibia, Botswana, Zambia, Zimbabwe, Malawi, Mozambique and South Africa are believed to be the centres of diversity of cowpea where primitive and wild relatives are found [11]. Diverse cowpea germplasm collections are conserved in the Southern African Development Community (SADC) gene bank in Lusaka/Zambia. The country serves as Plant Genetic Resources Centre coordinating the works 
of some 16 National Plant Genetic Resources Centres (NPGRCs) in southern Africa [12]. Farmers in southern Africa widely grow unimproved landraces due to a lack of improved and locally adapted farmer-preferred cultivars. Landraces exhibit low yield potential, heterogeneous in flowering and maturity, poor processing quality, and low palatability and digestibility [13]. Low palatability and digestibility are adaptive traits against field and storage pests, traits resulted from repeated cycles of natural and artificial selection. The low palatability and digestibility of landraces reduce their utility for human consumption due to prolonged cooking time and reduced bioavailability of essential nutrients. Therefore, the cowpea genetic resources found in the region can be explored as a novel source of genetic variation for breeding programs.

A well-characterised crop genetic resource is a precondition for effective breeding and genetic conservation. Genetic diversity is assessed using phenotypic traits and molecular markers. Phenotypic characterisation in the target production environment enables identification and quantification of genetic variation for key qualitative and quantitative traits for ideotype breeding. Knowledge of phenotypic variation and traits relationship assist crop breeders to develop the most adaptive and productive cultivars [14]. The genetic diversity of cowpea for phenotypic traits is assessed using standard descriptors developed by the International Board for Plant Genetic Resource [15]. Key phenotypic traits include days to flowering, time to maturity, growth habit, flower colour, number of pod plant ${ }^{-1}$, pod length, number of seeds pod ${ }^{-}$ ${ }^{1}$, seed colour, seed size, hundred seed weight and grain yield [15].

Various DNA markers such as the restriction fragment length polymorphism (RFLP), amplified fragment length polymorphism (AFLP), simple sequence repeat (SSR), random amplified polymorphic DNA (RAPD) and single nucleotide polymorphisms (SNP) have been used in cowpea genetic diversity analysis $[16 ; 17 ; 18]$. SNPs are markers of choice in genetic diversity analysis because they are widely distributed throughout the genome and their detection is amenable to automation [19]. In addition, SNP markers are increasingly time and cost efficient to genotype large populations with a relatively higher throughput [20]. SNP markers were applied in genetic diversity analysis of cowpea [16].

Cowpea is one of food security crops in Zambia widely cultivated in the eastern, southern and western regions. Hitherto, only seven cowpea varieties were released in the country that are relatively poor performers $(<700 \mathrm{~kg} / \mathrm{ha})$ and largely succumbed to emerging pests and diseases. The genetic diversity present among the germplasm collections conserved in the gene bank and landraces cultivated by smallholder farmers in Zambia can be explored for cowpea breeding and new cultivar deployment. Therefore, the objectives of the present study were to 
determine the extent of genetic diversity present among a collection of cowpea accessions from Zambia and Malawi using phenotypic traits and SNP markers, and to select distinct and complementary parental lines for cultivar development in Zambia.

\section{Results}

\section{Analysis of variance based quantitative phenotypic traits across locations}

The combined analysis of variance revealed that the genotype $\times$ site interaction effects were significant $(\mathrm{p}<0.05)$ for PDL, NPP and NSP (Table 2). DTF, DTM, PDL and NPP varied significantly $(\mathrm{p}<0.05)$ between the two sites. The genotypes had varied flowering and maturity date as revealed by the significant $(\mathrm{p}<0.05)$ genotypic effect. Similarly, there was significant $(\mathrm{p}<0.05)$ genotype difference for PDL, NSP, HSW and GYD.

\section{Mean performance of cowpea genotypes}

The mean days to flowering of the test genotypes was 41 days. DTF varied from 22 days (for the genotype BB10-4-2-5) to 59 days (Kapita black) (Table 3). The mean DTM of test genotypes was 74 days. Genotype ZM2960 was relatively early maturing with 60 days to maturity. Other early maturing genotypes included BB10-4-2-5 (62 days), Lutechipata and ZM6680 (63 days). The number of pods per plant varied from 13 to 33. Genotypes MS1-8-14, CP411, BBXSC103 and Kapita black had the highest NPP (> 30 pods plant ${ }^{-1}$ ). Pod length varied amongst genotypes. The longest pod were recorded for BBXSC13 and MS1-8-1-4 with a mean of $21 \mathrm{~cm}$. The genotypes that recorded higher number of seeds per pod were Bubebe, CP421 and CP 3422 with 18.50, 18.25 and 18.25 seeds per pod, respectively.

Heavier hundred seed weight was recorded for the genotypes Kapita (15.95 g/100 seed), CP2980 and ZM6680 (15.55). There existed significant genotype difference for GYD ranging from $87 \mathrm{~kg} \mathrm{ha}^{-1}$ (for genotype ZM 6680) to $2197.7 \mathrm{~kg} \mathrm{ha}^{-1}$ (CP411). The overall mean GYD of test genotypes was $748.56 \mathrm{~kg} \mathrm{ha}^{-1}$. Genotypes Chimponongo (with mean GYD of $2093.2 \mathrm{~kg}$ $\mathrm{ha}^{-1}$ ), CP645 (1899 $\left.\mathrm{kg} \mathrm{ha}^{-1}\right)$ and MS1-8-1-4 (1779.80 $\left.\mathrm{kg} \mathrm{ha}^{-1}\right)$ were among the top yielding selections. Overall, the following test genotypes were selected: Bubebe, BBXSC13, Chimponongo, CP411, CP645 and MS1-8-1-4 based on suitable and complementary quantitative agronomic traits. These genotypes are recommended as breeding parents to develop cowpea-breeding populations. 
Table 2. Mean squares and significant tests among 100 cowpea germplasm collections evaluated based on eight quantitative agronomic traits in two locations in Zambia.

\begin{tabular}{|c|c|c|c|c|c|c|c|c|c|}
\hline Source of variation & $\mathrm{DF}$ & DTF & DTM & PDL & NPP & NSP & SDS & HSW & GYD \\
\hline Location (L) & 1 & $702.20^{*}$ & $13806.30 * * *$ & $542.61 * * *$ & $2550.25 * * *$ & 29.7 & 0.01 & 6.30 & 107770.00 \\
\hline $\operatorname{Rep}(\mathrm{R})$ & 2 & 8.30 & $1731.08 * * *$ & $56.94 * *$ & 20.91 & 1.72 & 2.40 & 0.67 & 388357.00 \\
\hline Block (B) & 18 & 196.90 & 167.30 & 8.84 & 61.44 & $14.77 *$ & $5.09 *$ & $13.25^{*}$ & $1070734.00 * * *$ \\
\hline Genotype (G) & 99 & $242.50 *$ & $154.70^{*}$ & $14.02 *$ & 64.44 & $11.93^{*}$ & 2.10 & $10.26^{*}$ & $532280.00 * * *$ \\
\hline Genotype $\times$ location & 99 & 161.00 & 124.30 & $15.13^{*}$ & $71.32 *$ & $11.24 *$ & 1.06 & 8.15 & 233499.00 \\
\hline Residual & 180 & 148.00 & 107.20 & 10.66 & 50.41 & 8.66 & 1.72 & 7.07 & 207464.00 \\
\hline Total & 399 & 177.60 & 168.40 & 14.08 & 65.69 & 10.41 & 1.80 & 8.38 & 334119.00 \\
\hline
\end{tabular}

Note: $*, * * * * *=$ Significance at $10 \%, 5 \%$ and $1 \%$, respectively; ns = not significant; DF: degrees of freedom; DTF: days to flowering; DTM: days to maturity; PDL: pod length (cm), NPP: number of pods per plant; NSP: number of seeds per pod, SDS: seed size; HSW: hundred seed weight (g) and GYD: grain yield in kg per hectare 
Table 3. Mean values for grain yield and yield components of 100 cowpea genotypes showing the top 10 and bottom 5 ranked genotypes based on grain yield $(\mathrm{kg} / \mathrm{ha})$ when assessed in two locations in Zambia

\begin{tabular}{|c|c|c|c|c|c|c|c|c|}
\hline Genotype & $\overline{\text { DTF }}$ & DTM & PDL & NPP & NSP & SDS & HSW & GYD \\
\hline \multicolumn{9}{|c|}{ Top 10 genotypes } \\
\hline CP411 & 34.50 & 73.75 & 20.15 & 32.25 & 16.50 & 3.00 & 13.48 & 2197.70 \\
\hline Chimponongo & 51.50 & 79.50 & 19.52 & 26.75 & 16.75 & 5.00 & 20.95 & 2093.20 \\
\hline CP645 & 51.00 & 73.25 & 20.68 & 28.00 & 17.25 & 4.50 & 13.48 & 1899.30 \\
\hline MS1-8-1-4 & 39.75 & 68.50 & 21.20 & 33.25 & 15.50 & 5.00 & 15.03 & 1779.80 \\
\hline CP732 & 34.75 & 81.00 & 17.02 & 22.25 & 16.00 & 4.50 & 15.50 & 1672.40 \\
\hline BB14-16-2-2 & 36.75 & 74.00 & 19.70 & 25.25 & 15.50 & 3.00 & 11.25 & 1501.90 \\
\hline ZM3003 & 39.00 & 74.50 & 16.68 & 18.50 & 13.50 & 6.00 & 14.08 & 1454.10 \\
\hline CP421 & 44.75 & 72.75 & 19.90 & 24.00 & 18.25 & 3.00 & 16.23 & 1328.20 \\
\hline $\mathrm{CP} 2$ & 39.50 & 75.00 & 17.53 & 26.75 & 16.25 & 4.50 & 11.75 & 1252.70 \\
\hline CP601 & 40.00 & 73.50 & 17.85 & 22.25 & 16.75 & 5.50 & 13.83 & 1237.80 \\
\hline \multicolumn{9}{|c|}{ Bottom 5 genotypes } \\
\hline ZM2966 & 38.50 & 74.50 & 17.25 & 18.75 & 13.75 & 4.00 & 13.43 & 227.10 \\
\hline CP2231 & 45.75 & 77.00 & 15.41 & 16.75 & 12.75 & 6.00 & 15.13 & 225.40 \\
\hline ZM2954 & 47.00 & 73.75 & 15.90 & 19.25 & 13.50 & 5.50 & 14.68 & 188.20 \\
\hline CP1769 & 35.25 & 73.00 & 18.63 & 21.25 & 17.25 & 5.00 & 13.55 & 126.00 \\
\hline ZM6680 & 29.25 & 62.75 & 12.30 & 16.50 & 11.25 & 5.00 & 15.55 & 87.00 \\
\hline Mean & 41.10 & 73.86 & 17.98 & 21.40 & 15.60 & 4.20 & 12.93 & 748.56 \\
\hline Minimum & 14.00 & 31.00 & 6.00 & 3.00 & 0.00 & 3.00 & 9.10 & 32.55 \\
\hline Maximum & 80.00 & 96.00 & 27.20 & 56.00 & 24.00 & 7.00 & 28.50 & 5471.24 \\
\hline SE & 8.60 & 7.32 & 2.31 & 5.02 & 2.08 & 0.92 & 1.88 & 322.10 \\
\hline $\operatorname{LSD}(5 \%)$ & 16.97 & 14.50 & 4.56 & 9.90 & 4.11 & 1.83 & 3.71 & 635.50 \\
\hline $\mathrm{CV}(\%)$ & 29.60 & 14.02 & 18.16 & 33.18 & 18.86 & 31.09 & 20.55 & 60.85 \\
\hline
\end{tabular}

Note: CV: coefficient of variation; LSD: least significant difference; SE: standard error; DTF: days to flowering; DTM: days to maturity; PDL: pod length (UNIT?); NPP: number of pods per plant; NSP: number of seeds per pod; SDS: seed size (mm); HSW: hundred seed weight (g/100 seed); GYD: grain yield in $\mathrm{kg} \mathrm{ha}^{-1}$

\section{Variation based on qualitative phenotypic traits}

There were significant differences $(\mathrm{P}<0.00)$ among test genotypes for key qualitative traits (Additional file 1). For growth habit, 43 of the accessions were indeterminate, 39 determinate 
and 18 creeping types. Genotypes with predominantly upright growth type and short plant height were Bubebe, Namuseba, Msandile and MS1-8-1-4. Chimponongo and BBXSC13 had creeping growth type. Forty-nine accessions had brown and 21 black seed coat colour, while the rest of the genotypes had 12 purple- brown, 10 white and 8 red- brown. Based on leaf colour genotypes were assorted into light green (26 genotypes), light green (35) and dark green (39). Pod colour was variable varying from deep green (52 genotypes), light green (30) and purple (18). There were three classes of genotypes based on flower colour: 95 genotypes displayed violet flower, while four had yellow and one had white. Therefore, a combination of the assessed qualitative traits are useful markers for genotype selection in cowpea improvement programs.

\section{Variance components and heritability of quantitative agronomic traits}

Phenotypic coefficient of variation (PCV) values were higher than genotypic coefficient of variation (GCV) for all the traits (Table 4). The GCV values ranged from 0 to $14.6 \%$, while the PCV ranged from 0 to $21.56 \%$. Larger discrepancies between GCV and PCV estimates were observed for all assessed traits. The genotypic variance accounted for $\geq 50 \%$ of the total variation for grain yield. Low heritability $(\leq 30)$ estimates were recorded for days to maturity, hundred seed weight, number of seed pod $^{-1}$ and pod length and number of pod plant ${ }^{-1}$. The heritability estimates for days to flowering and seed size were moderate (30-60\%), while grain yield recorded heritability estimates above $60 \%$ that will enhance the response to selection and breeding gains. Genetic advance ranged from 0 to $20.58 \%$. Seed size and days to flowering had moderate GA\% (10-20\%).

Table 4. Estimates of variance components and genetic parameters for yield and yield components among 100 cowpea genotypes evaluated in two locations in Zambia

\begin{tabular}{lllllllll}
\hline Component & DTF & DTM & PDL & NPP & NSP & SDS & HSW & GYD \\
\hline Genotype (G) & 21.75 & 9.27 & 0.00 & 0.00 & 0.42 & 0.38 & 0.57 & 0.10 \\
Location (L) & 148.31 & 125.56 & 11.10 & 50.46 & 8.65 & 1.78 & 7.48 & 0.23 \\
G x L & 6.32 & 0.00 & 2.01 & 10.43 & 1.30 & 0.00 & 0.34 & 0.00 \\
Total (G + L + G x L) & 176.38 & 134.83 & 13.12 & 60.89 & 10.37 & 2.17 & 8.39 & 0.34 \\
Phenotypic variance & 61.99 & 40.66 & 3.78 & 17.83 & 3.23 & 0.83 & 2.61 & 0.16 \\
Heritability (\%) & 35.00 & 23.00 & 0.00 & 0.00 & 13.00 & 46.00 & 22.00 & 64.00 \\
GCV (\%) & 11.35 & 4.12 & 0.00 & 0.00 & 4.14 & 14.68 & 5.82 & 0.04 \\
PCV (\%) & 19.16 & 8.63 & 10.82 & 19.73 & 11.52 & 21.58 & 12.48 & 0.05 \\
GA & 5.69 & 2.99 & 0.00 & 0.00 & 0.48 & 0.87 & 0.72 & 0.53 \\
GA (\%) & 13.85 & 4.05 & 0.00 & 0.00 & 3.07 & 20.58 & 5.60 & 0.07 \\
\hline
\end{tabular}


GCV: genotypic coefficient of variation; PCV: phenotypic coefficient of variation; GA: genetic advance; GA (\%): genetic advance as a percentage of the mean: DTF: days to flowering; DTM: days to maturity; PDL: pod length; NPP: number of pods per plant; NSP: number of seeds per pod; SDS: Seed Size; HSW: hundred seed weight (g); GYD: grain yield in $\mathrm{kg}$ per hectare

\section{Correlations among quantitative traits}

Phenotypic correlation coefficients among assessed quantitative traits is summarised in Table 5. Grain yield showed significant $(\mathrm{P} \leq 0.05)$ correlations with PDL $(\mathrm{r}=0.42)$, NPP $(\mathrm{r}=0.50)$ and NSP $(r=0.46)$. The following traits exhibited significant $(\mathrm{P} \leq 0.05)$ correlations: DTF and DTM $(\mathrm{r}=0.66)$, PDL with NPP $(\mathrm{r}=0.44)$ and NSP $(\mathrm{r}=0.64)$. NPP and NSP were significantly correlated $(\mathrm{r}=0.38)$, while HSW and SDS exhibited a relatively stronger association $(\mathrm{r}=0.51)$.

Table 5. Correlation coefficients of grain yield and yield components among 100 cowpea genotypes evaluated at two locations in Zambia

\begin{tabular}{lrrrrrrrr}
\hline Traits & DTF & \multicolumn{1}{c}{ DTM } & \multicolumn{1}{c}{ PDL } & NPP & NSP & SDS & HSWT & GYD \\
\hline DTF & 1 & & & & & & & \\
DTM & $0.66^{* *}$ & 1 & & & & & & \\
PDL & -0.05 & 0.01 & 1 & & & & & \\
NPP & -0.05 & -0.05 & $0.43^{* *}$ & 1 & & & & \\
NSP & -0.05 & 0.03 & $0.64^{* *}$ & $0.38^{* *}$ & 1 & & & \\
SDS & -0.01 & 0.00 & -0.04 & -0.09 & $-0.30^{* *}$ & 1 & & \\
HSW & 0.01 & -0.06 & 0.07 & -0.09 & -0.12 & $0.51^{* * *}$ & 1 & \\
GYD & -0.05 & -0.07 & $0.42^{* *}$ & $0.50^{* *}$ & $0.46^{* *}$ & -0.12 & 0.04 & 1 \\
\hline
\end{tabular}

Note: $* * . * * *=$ Significant at $5 \%$ and $1 \%$ respectively; DTF: days to flowering; DTM: days to maturity; PDL: pod length $(\mathrm{cm})$, NPP: number of pods per plant; NSP: number of seeds per pod, HSW: hundred seed weight (g), GYD: grain yield in kg per hectare

\section{Principal component (PC) and bi-plot analyses}

The first three PCs with Eigen-values greater than 1 accounted for $71.25 \%$ of the total variation exhibited by the assessed quantitative traits (Table 6). The first principal component (PC1) accounted for $31.5 \%$, while PC2 and PC3 contributed to 20.97 and $18.78 \%$, respectively, of the total variation. The highest contributing traits correlated with PC1 were PDL (0.84), NSP (0.82), GYD (0.75), and NPP (0.72). The loadings on PC2 were mostly contributed by DTF (0.84) and DTM (0.87), while HSW (0.80) and SDS (0.78) had the largest contributions to the variation correlated with PC3.

The relationships among the different traits and genotypes and their association with the respective principal components are further illustrated by the principal component biplot 
presented in Figure 1. The biplot dimension vectors showed a high positive correlation among traits GYD, NPP, NSP and PDL, as well as among DTF, DTM, HSW, and SDS. Most of the tested accessions were scattered in the positive side of the first principal component, with genotypes E10 (CP411), E71 (LT16-7-2-5), E13 (CP421) and E20 (CP645) excelling in grain yield and yield components.

Table 6. Eigen values, variances and loading scores of eight quantitative traits among 100 cowpea genotypes assessed in two locations in Zambia

\begin{tabular}{lrrr}
\hline Traits & PC1 & PC2 & PC3 \\
\hline Eigen-values & 2.52 & 1.68 & 1.50 \\
Proportion variance (\%) & 31.49 & 20.97 & 18.78 \\
Cumulative variance (\%) & 31.49 & 52.46 & 71.25 \\
DTF & -0.09 & 0.88 & -0.22 \\
DTM & -0.03 & 0.87 & -0.27 \\
PDL & 0.84 & 0.06 & 0.04 \\
NPP & 0.72 & 0.02 & 0.13 \\
NSP & 0.82 & -0.01 & -0.21 \\
SDS & -0.25 & 0.18 & 0.78 \\
HSW & 0.02 & 0.31 & 0.80 \\
GYD & 0.75 & 0.11 & 0.27 \\
\hline
\end{tabular}

DTF: days to flowering; DTM: days to maturity; PDL: pod length (cm), NPP: number of pods per plant; NSP: number of seeds per pod, HSW: hundred seed weight (g), GYD: grain yield in kg per hectare $\mathrm{PC}=$ principal component 


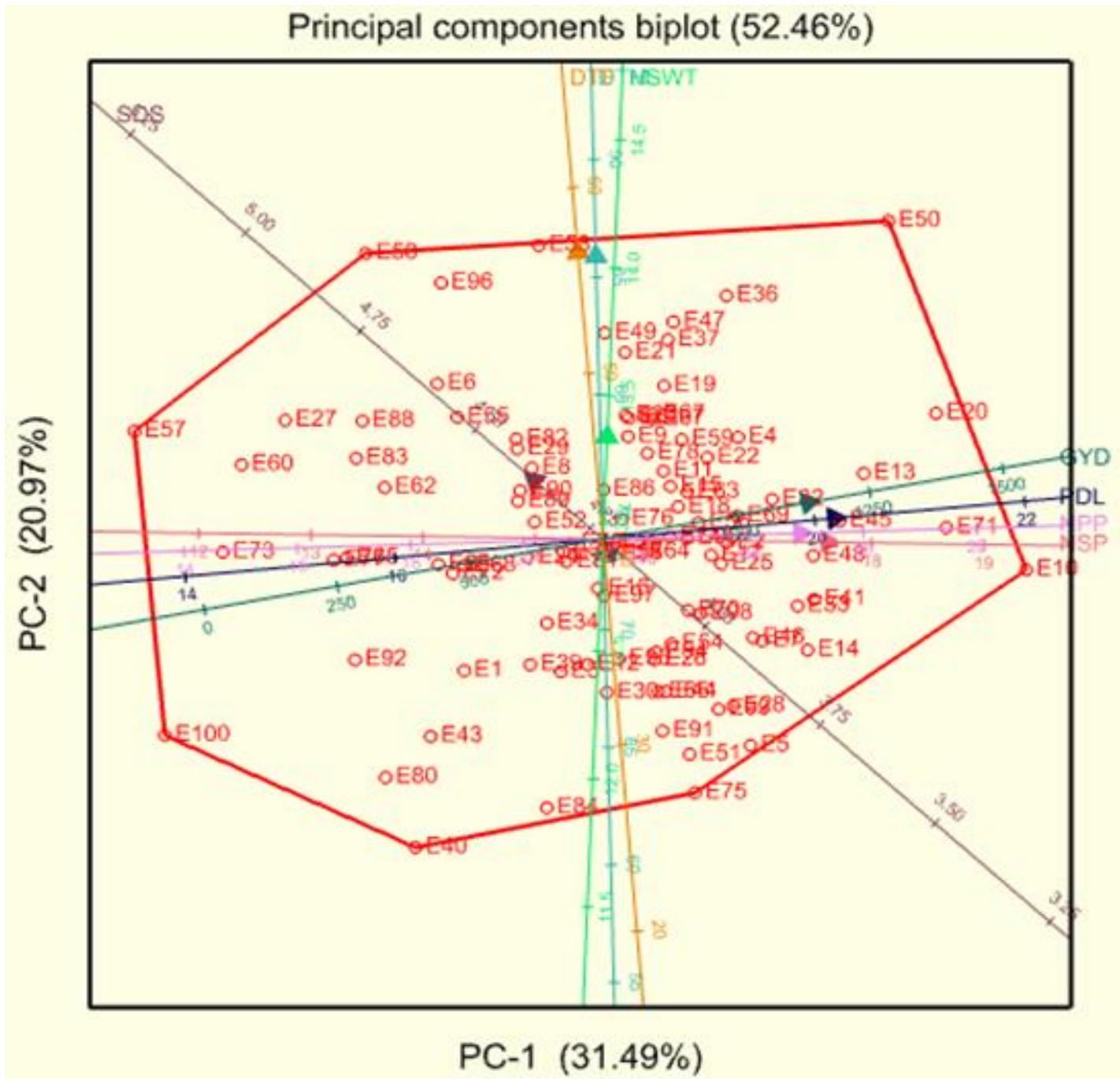

Figure 1. Genotype-trait biplot showing association of eight quntitative traits in 100 genotypes of cowpea assessed in two loactions.

Note: DTF: days to flowering; DTM: days to maturity; PDL: pod length (cm), NPP: number of pods per plant; NSP: number of seeds per pod, HSW: hundred seed weight (g), GYD: grain yield in kg per hectare PC-1 and PC-2: principal component 1 and principal components 2, respectively

\section{Genetic diversity and population structure}

The tested SNP markers were moderately polymorphic with a mean PIC value of 0.17 for the whole population and 0.21 for the mutant lines (Table 7). The mutant lines also exhibited the highest gene diversity (GD) with a mean of 0.26 . The highest mean minor allele frequency was 0.22 observed among landraces. The whole population had high heterozygosity (0.30). Among the biological types, mutant lines exhibited the highest heterozygosity estimate with a mean of 0.35 . The heterozygosity values fell within a range of 0.25 and 0.36 . The elite lines exhibited 
the highest inbreeding index of -0.37 while the landraces and mutant lines had indices of -0.34 and -0.35 , respectively. Overall, the level of inbreeding ranged between -0.52 and -0.13 .

Table 7. Genetic parameters of 90 cowpea germplasm collections assessed based on 14,116 SNP markers

\begin{tabular}{lllllc}
\hline Biological type & GD & PIC & MAF & Ho & F \\
\hline Whole population & 0.22 & 0.17 & 0.18 & 0.30 & -0.35 \\
Elite lines & 0.21 & 0.17 & 0.19 & 0.30 & -0.37 \\
Landraces & 0.22 & 0.18 & 0.22 & 0.23 & -0.34 \\
Mutant lines & 0.26 & 0.21 & 0.18 & 0.35 & -0.35 \\
Range & $0-0.5$ & $0-0.38$ & $0-0.5$ & $0.25-0.36$ & $-0.52--0.13$ \\
GD, genetic diversity; PIC, polymorphic information content; MAF, minor allele frequency, \\
Ho, observed heterozygosity; F, inbreeding coefficient
\end{tabular}

The structure analysis based on the Evanno method allocated the test genotypes into four main clusters with the highest value of $\Delta \mathrm{K}$ that occurred at $\mathrm{K}=4$ (Figure 2A). Genotypes that scored $<0.80$ were considered as pure line populations, while those that were $<0.80$ as admixtures (Figure 2A). The model-based clustering using the 90 accessions showed the four admixture sub-populations (Figure 2C). Sub-population I was composed of 16 accessions (17.7\%) that were sourced from Malawi and the University of Zambia. About 22 accessions (24.4\%) were allocated in sub-population II and these genotypes were mainly acquired from Malawi, the National Gene Bank of Zambia and the University of Zambia. Sub-population III was the largest group, consisting of 35 accessions (38.9\%). Members of this sub-population were landraces and elite lines sourced from the National Gene Bank, and the University of Zambia. Sub-population IV consisted of 17 accessions (18.9\%) obtained from the University of Zambia and the National Gene Bank. The sub-population II (University of Zambia) and III (National Gene Bank) were characterized by mean Fst values of 0.57 and 0.69 , respectively. Principal coordinate analysis (PCoA) assigned the accessions to four admixture groups. In particular, sub-populations I and II were clustered in PC1, while sub-populations III and IV were dominant in PC2 (Figure 2B). 


\section{A}

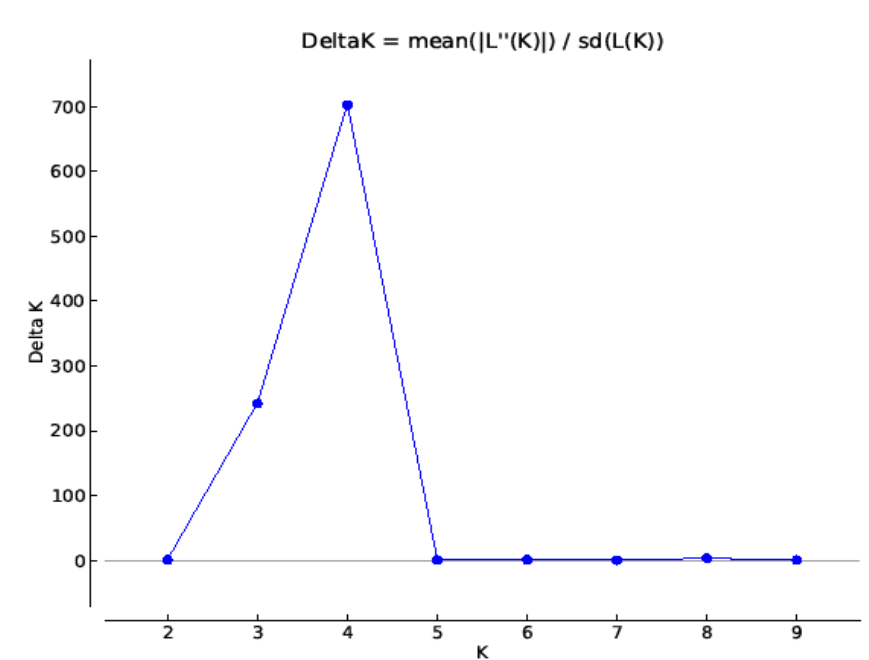

$$
\text { B }
$$

1

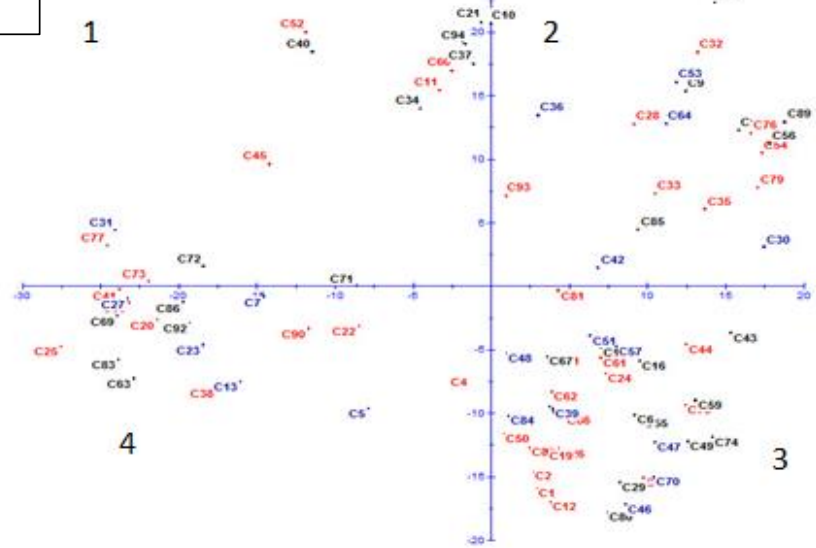

\section{C}

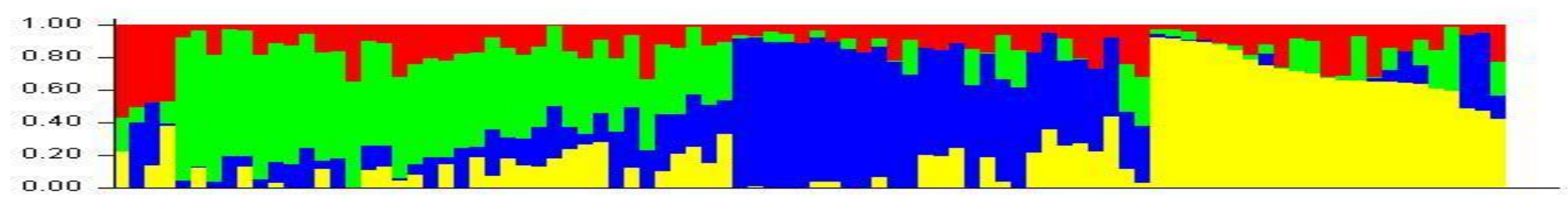

Figure 2. Subpopulation inference among the 90 cowpea accessions based on 14166 SNPs showing (A) likelihood and delta K values for different number of assumed clusters, (B) principal coordinate analysis clustering of the genotypes and (C) population structure at $\mathrm{K}=4$. 
The analysis of molecular variance (AMOVA) showed a significant variation within populations. The within population variation accounted for $92 \%$ of the total variance (Table 8). The variation detected among the populations was not significant and explained only $8 \%$ of the variability in the germplasm. The lack of genetic variation among the populations was confirmed by the low pair-wise genetic differentiation (Fst) values ranging between -0.004 and 0.012 and inbreeding coefficient (Fis) of -0.351 to -0.362 (Table 9).

Table 8. Analysis of molecular variance involving 90 cowpea accession based on source of collection

\begin{tabular}{lccccc}
\hline Source & Df & SS & MS & Estimated Variance. & Proportion of variance \\
\hline Among Populations & 2 & 45.57 & 22.78 & 0.54 & $8 \%$ \\
Within Populations & 82 & 537.96 & 6.56 & 6.40 & $92 \%$ \\
Total & 84 & 583.53 & 6.95 & \\
\hline Df=degran &
\end{tabular}

$\mathrm{Df}=$ degrees of freedom, $\mathrm{SS}=$ sum of squares, $\mathrm{MS}=$ mean squares

Table 9. Genetic differentiation (Fst) and inbreeding coefficients (Fis) among elite lines, landraces and mutant lines of cowpea evaluated in this study

\begin{tabular}{lccc}
\hline Populations & Inbreeding coefficient (Fst) & \\
\hline & $\mathrm{G} 1$ & $\mathrm{G} 2$ & $\mathrm{G} 3$ \\
$\mathrm{G} 1$ & - & 0.006 & 0.012 \\
G2 & -0.364 & - & -0.004 \\
G3 & -0.374 & -0.351 & - \\
& Genetic differentiation (Fis) & \\
\hline
\end{tabular}

G1 includes all breeding elite lines, G2 is comprised of landraces collected from farmers in Zambia, G3 consists of mutant lines

\section{Combined analysis of phenotypic and genotypic data}

The dendrograms for phenotypic and genotypic data each revealed three heterogeneous clusters among the genotypes. The phenotypic dendrograms showed that the first cluster comprised of genotypes from all sources, while the second cluster comprised of elite lines from Malawi, 
University of Zambia and the National Gene Bank and the last cluster contained accessions from the National Gene Bank, Malawi and the University of Zambia (Figure 3). The largest cluster in the genotypic dendrogram contained genotypes from the National Gene Bank, while the second largest consisted of mostly genotypes from Malawi (Figure 4). The joint matrix revealed three similarly sized clusters among the genotypes (Figure 5). The phenotypic and genotypic dendrograms were compared using the tanglegram and only a few genotypes (about 10\%) maintained their positions (Figure 6). The tanglegram comparison highlighted that both the positions and groupings of the genotypes were not consistent across the phenotypic and genotypic dendrograms. A relatively few genotypes maintained their position, i.e., about $30 \%$ maintained their groupings. Furthermore, the phenotype and genotype dissimilarity matrices exhibited a very low correlation ( $\mathrm{r}=-0.03)$ when subjected to the Mantel test (Additional files 2 and 4). In contrast, the genotype and phenotype dissimilarity matrices each exhibited strong correlations of $\mathrm{r}=0.12$, and $\mathrm{r}=0.99$ with the joint matrix, respectively (Additional files 5 and 6 ).

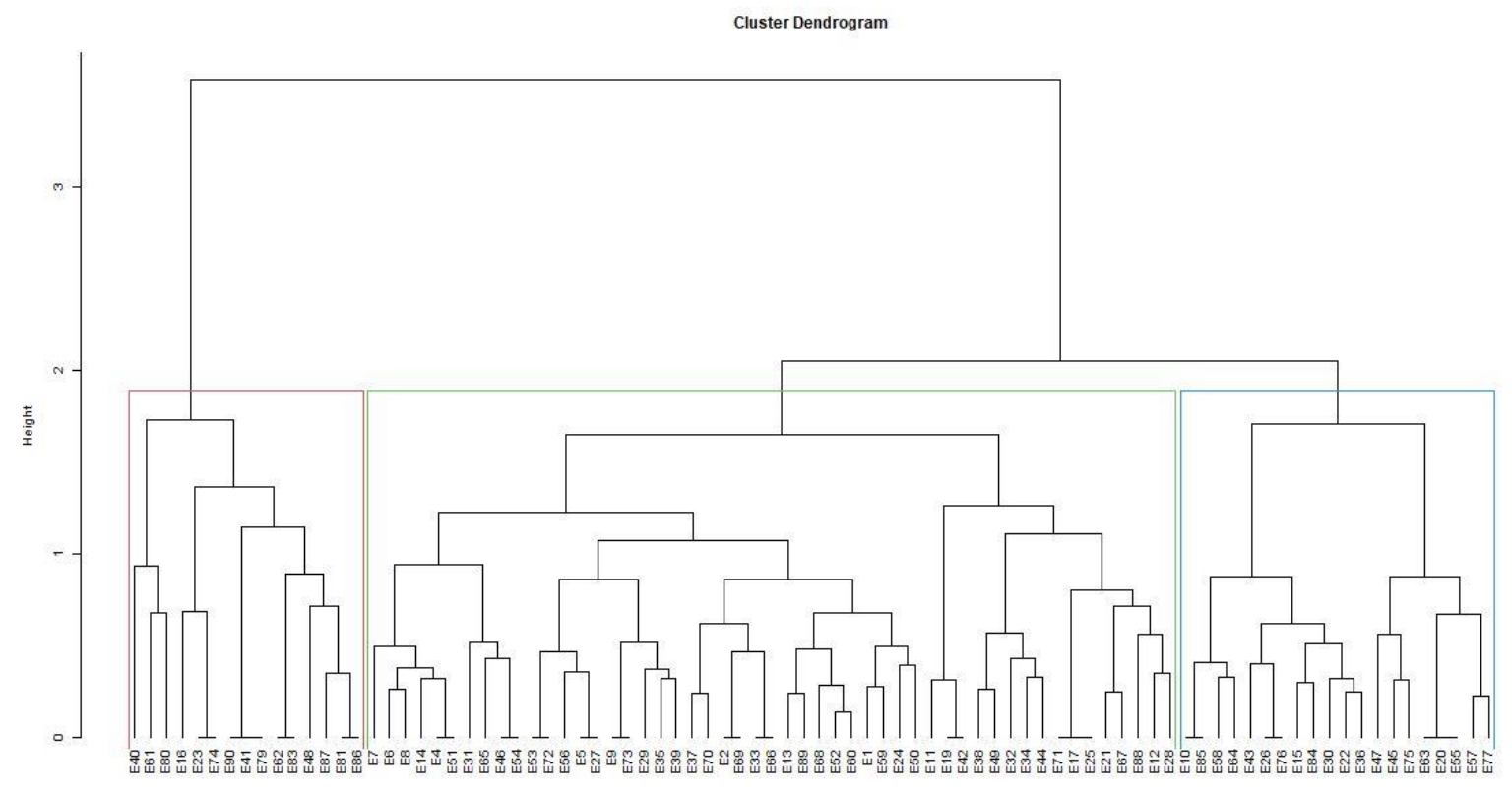

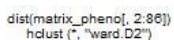

Figure 3 Dendrogram showing relatedness among the 90 cowpea genotypes based on phenotypic matrix 


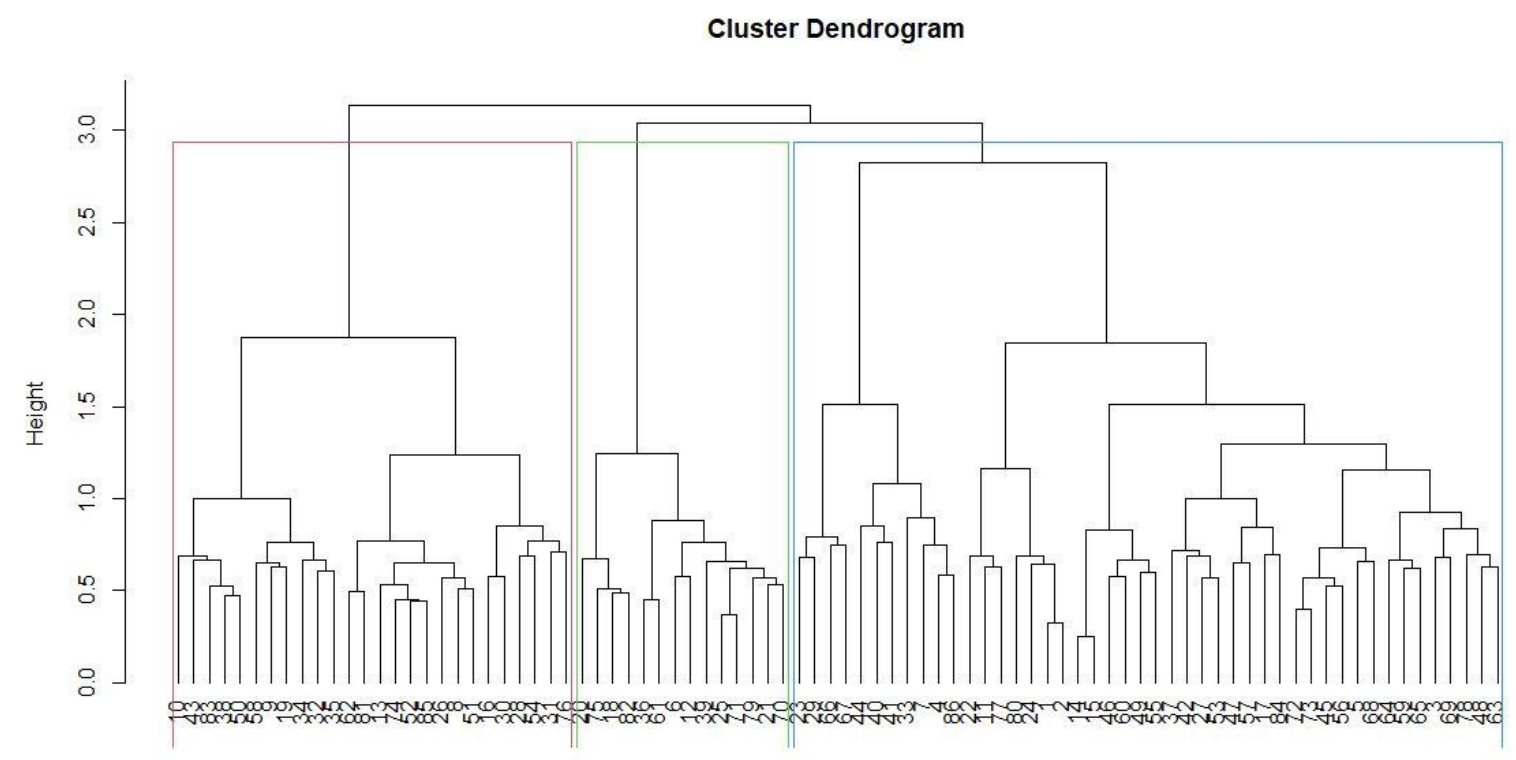

dist(genomatrice2[, 2:86])

hclust (*, "ward.D2")

Figure 4. Dendrogram showing relatedness among the 90 cowpea genotypes based on genotypic matrix

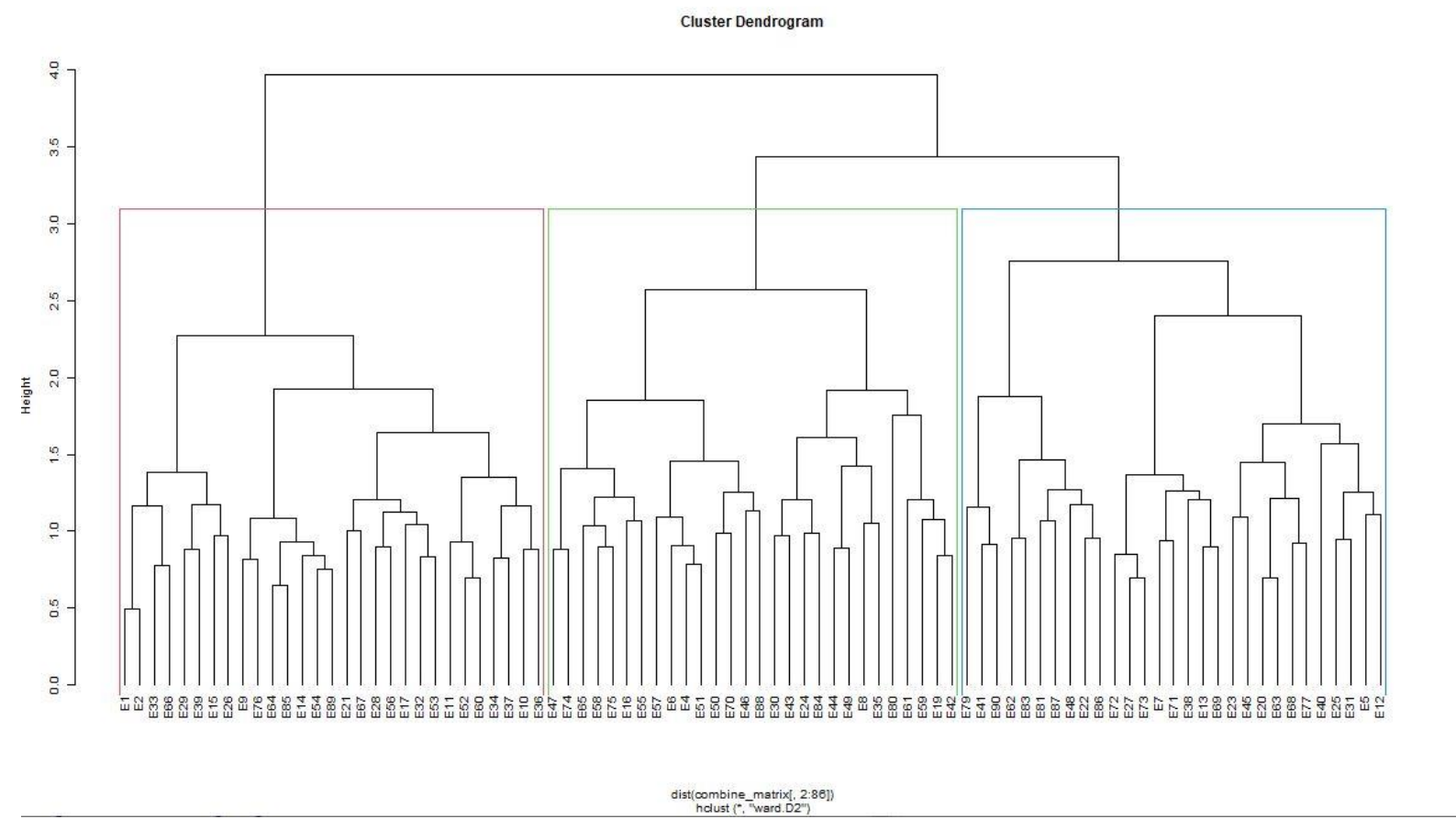

Figure 5. Dendrogram showing relatedness among the 90 cowpea genotypes based on joint matrix 

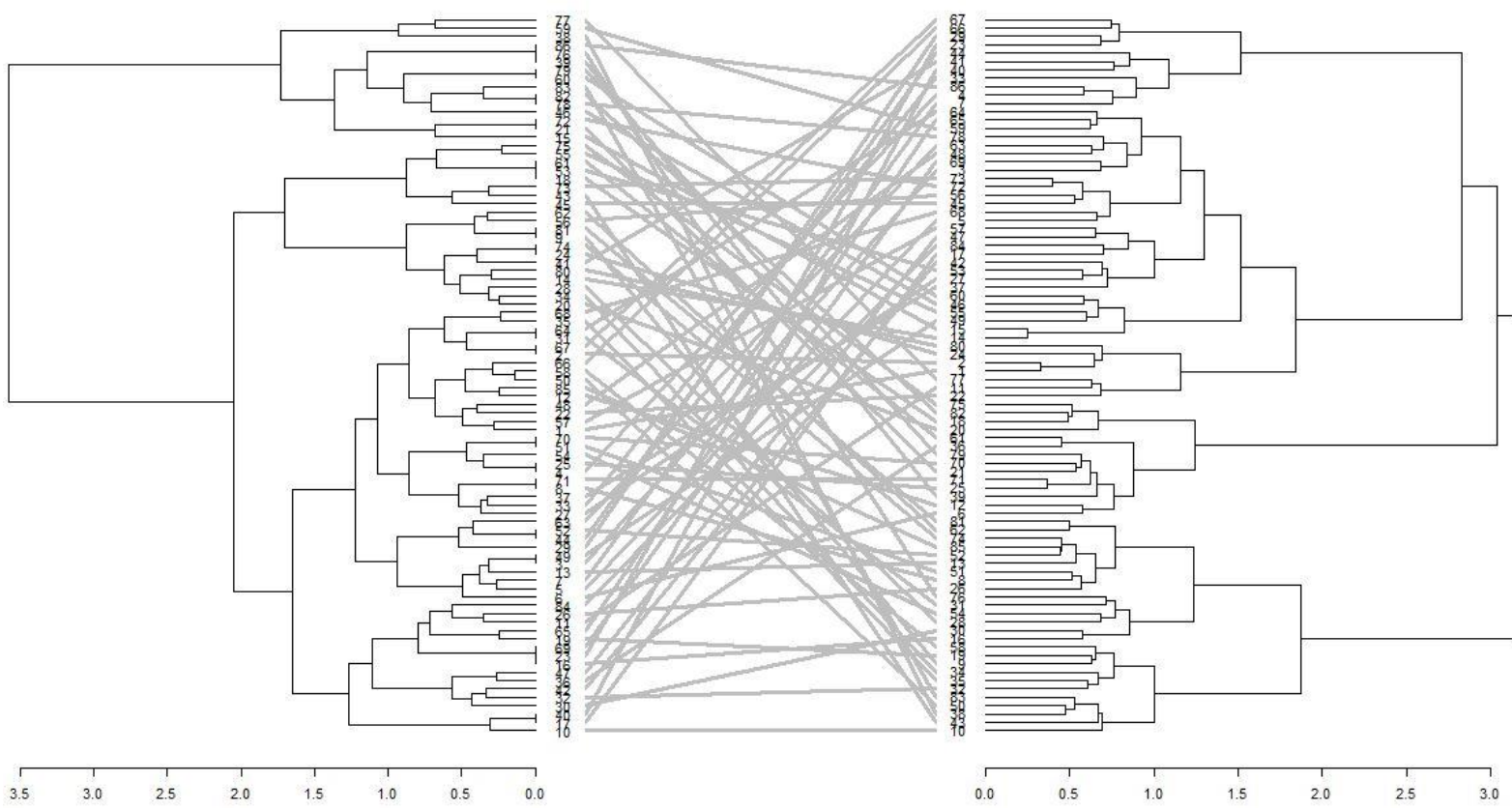

Figure 6. Tanglegram showing comparison of phenotypic and genotypic dendrograms

\section{DISCUSSION}

\section{Genotypic variation and performance of test genotypes for key qualitative and quantitative traits}

The present study evaluated the genetic diversity present among 100 diverse genotypes of cowpea germplasm collections from southern Africa using qualitative and quantitative phenotypic traits in two locations in Zambia. Further, high density SNP markers were used as a preliminary step to identify suitable and complementary parental lines for breeding. There were significant genotype $\times$ location interaction (Table 2) effect signifying that the tested germplasm were genetically diverse for selection and cultivar development targeting the test locations. Also, the interaction effect shows that the genotypes responded differently in the test environments which can facilitate identification of cowpea lines with specific or broad adaptation. Specific and broad adaptation have been identified and exploited in the Brazilian cowpea breeding programs based on genotype $\times$ location interaction analysis [21]. The interaction effect suggests that the test environments influence genotypic performance, which may confound genotype selection efforts by reducing the correlation between genotype and phenotypic expression [22]. 
In the present study, the assessed quantitative traits were affected by genotype $\times$ location interaction effect. Hence, there is intrinsic genetic variation influenced by the test locations necessitating multi environment evaluation for selection. Differential genotype response to environmental conditions during germplasm evaluation is attributable to the differences in genetic constitution among test genotypes and micro-environmental conditions [23]. In this study, the SCCI (mean yield of $832 \mathrm{~kg} \mathrm{ha}^{-1}$ ) site is high yielding environment compared with the GART (mean yield of $764 \mathrm{~kg} \mathrm{ha}^{-1}$ ) site probably due to the prevailing favourable environmental conditions such as better soil fertility and higher moisture levels in the former. Genotype phenology and biomass production exhibit environmental plasticity due to variable soil and climatic factors $[24 ; 25]$. In the present study, some genotypes were high grain yielders (e.g. CP411 with $2197 \mathrm{~kg} \mathrm{ha}^{-1}$ ) and others were low yielders (e.g. ZM6680 with $87 \mathrm{~kg} \mathrm{ha}^{-1}$. Quantitative traits are under the influence of polygenes. Hence, it is pertinent for genotype selections in multiple test environments to minimise environmental variance and to enhance selection gains [27; 28]. Genotypes such as MS1-8-1-4, Msandile, BBXSC13, CP411, CP421, CP654, CP3413 and Bubebe that exhibited early to medium maturity are ideal candidates for drought tolerance breeding to offset the incessant droughts experienced in southern Africa. Early maturity is associated with drought escape [29]. [8] reported that farmers in southern Africa prefer cultivars with a short flowering period and maturity, valuable traits to evade the "hunger period". Highest number of seeds per pod (e.g. expressed by genotypes CP421 and Bubebe) is one of the factor affecting genotype responses based on their efficiency in growth resource utilisation and allocation. This could also be contributed to increased length of the pods by test genotypes [30]. Seed weight is directly associated with seed size and it is recommended to be used as an indirect selection criterion to maximise grain yield response in cowpea [10]. [8] reported a high yield potential of cowpea genotypes that can reach up to 3 t/ha. The yield level recorded in the present study by the landraces was relatively less. This could be the low yield potential of landraces grown by most farmers in SSA. In the region, landraces are continuously cultivated because they possess farmer-preferred quality traits and their ability to adapt under variable stress conditions due to their genetic diversity and plasticity $[31 ; 32]$.

In the present study qualitative traits such as seed coat, pod and leaf colour were more important traits for selection. These traits affect the market value of cowpea in Africa given that farmer and consumer preference are based on these attributes. Seed coat colour is often associated with processing quality (e.g. cooking time) and farmers deliberately select white seed types, which have shorter cooking time [33]. The inheritance of seed coat colour is governed by few 
major genes that will enhance selection progress during cultivar development [34]. In this study, the genotypes Bubebe and Msandile, with predominantly light-green leaves exhibited determinate growth habit in comparison with BBXSC13 and Chimponongo that had dark green leaves and creeping growth habit. [35] reported that cowpea cultivars with a determinate growth type were more drought tolerant compared to the indeterminate types. [36] reported that indeterminate varieties of cowpea attained higher productivity due to their prolonged maturity and photosynthesis efficiency. Therefore, in order to promote sustainable production and productivity and enhanced adoption of improved cowpea cultivars, breeding programs should incorporate farmer- and market- preferred attributes in the newly developed cultivars.

\section{Variance, heritability and genetic advance}

In this study, the heritability estimate for grain yield was high (64\%), suggesting that the grain yield achieved by the accessions was highly repeatable ensuring genetic improvement through selection. The high heritability value for grain yield corroborates with the findings of [37] but lower than a heritability value of $97 \%$ reported by [30]. Genetic advance is directly related with yield gains achievable via selection. High estimates of genetic advance (e.g. for HSW and SDS) and high heritability indicate that selection would result in foreseeable genetic improvement [38; 39]. The large discrepancies values of PCV compared to GCV in this study, suggests that trait expression was also influenced by environment factors in addition to genetic effects, which was also confirmed by the significant location main effects in the ANOVA (Table 2).

\section{Associations of quantitative traits}

The relationships among yield and yield components are critical in devising a selection strategy. Selection of one trait may amplify or negatively affect performance in the other traits. The high contribution and strong association of PDL, NSP, GYD, and NPP to PC1 as well as DTF and DTM with the PC2 indicated that these traits were highly discriminatory explaining the variation among the genotypes. [40] and [41] found that traits such as NPP and GYD in cowpea were associated with PC1 showing the importance of agronomic traits in cowpea evaluation corroborating with the findings of the present study. The genotype-trait biplot enables visual and simultaneous selection of genotypes for multiple traits. There was strong correlations between PDL, NPP, NSP and grain yield indicating their positive impact on genotype performance. Previous reports identified these traits being important yieldinfluencing attributes [30; 41]. Entries such as E10 (CP 411), E71 (LT16-7-2-5), E13 (CP421) and E20 (CP645) scored greater grain yield response and yield-influencing traits suggesting 
their utility in variety improvement for yield gains and breeding population development. Entries such as E10 (CP411), E20 (CP645), E13 (CP421) and E58 (Sundan1) are selected with desirable NSP, GYD, PDL and DTF, respectively.

\section{Population structure and genetic parameters}

Genetic analysis using SNP markers delineated the test populations in to four genetic groups. This demarcation was irrespective of source of collection, suggesting that geographical sources of collection are not the sole factor for classification of cowpea genotypes. The germplasm exhibited high heterozygosity of 0.30 , which showed that alternative alleles were represented in this population. This could be attributed to genetic exchange between and among cowpea breeding programs in sub-Sahara Africa, particularly in southern Africa. Heterozygosity estimates were highest for mutant lines, followed by elite lines and landraces. This suggests that mutant lines exhibited more variability possibly due to continuous gene segregation and other chromosomal aberrations. Landrace varieties are not subjected to artificial selection by breeders. Hence, landraces of self-pollinating crops including cowpea consists of heterogeneous populations due to genetic variation until complete homozygosity is reached through selection [42]. Mutant and elite lines are the result of several cycles of deliberate selection and inbreeding with expectedly high level of homozygosity at multiple loci. The present mutant lines were grouped together with the mother stocks or parental lines. This shows that the mutation events were minor and the genetic background largely remained the same for most of the assessed traits in the mutants lines compared with the elite parental lines. Malawi and Zambia are in close geographical proximity hence germplasm exchange between the two countries cannot be ruled out. Trait preference for the farmers and the market in the region may not be significantly different leading to the overlap of cowpea genetic resources in these agroecologies. This has partly disallowed the population structure analysis without distinguishing the genotypes based on geographical sources agreeing to the report of [18]. Exchange of genetic resources is key for plant-breeding research and cultivar development, which are dependent on wider genetic bases [10].

The PIC and GD values were essential to assess genetic diversity within the whole population, and sub-populations for identification selection of divergent parental lines useful for breeding. The moderate PIC and GD values exhibited by the whole population could be attributed to the inherent nature of self-pollination in cowpea, which limits genetic diversity. Self-pollinating species often lack genetic diversity due to higher levels of homozygosity at multiple loci. The within-population diversity in self-pollinating species is relatively low but varies among populations [43, 44]. In contrast, mutants lines exhibited higher Ho, PIC and GD values 
compared to the elite lines or landraces. Naturally, landraces of self-pollinating species would be expected to exhibit higher levels of homozygosity compared to mutant and elite lines that were subjected to deliberate mutagenesis and crossing during breeding. On the hand, mutant lines exhibited higher heterozygosity and PIC values than elite lines, which could be due induced random mutations. Mutation breeding is a well-established technique to widen genetic diversity [45]. However, the mutant and elite lines displayed difference in growth pattern. This may be attributed to genetic differences in plant architecture in terms of growth habit and maturity period, among others. For example, the elite line Bubebe and the mutant line MS1-8$1-4$, have short maturity period and determinate growth type. Hence, inclusion of landraces such as Chimponongo and Kapita with late maturity and creeping growth habit would be recommended to increase genetic variation and to enhance genetic gain through selection. This is consistent with the findings of other cowpea researches who indicated that architecture of the crop results in genetic diversification [9]. The mean Fst values recorded in the present study showed low genetic differentiation among the test populations (max Fst=-0.012), which could be attributed to the self-pollination nature of cowpea. This shows that the sub-groups account for a small proportion of the total variance exhibited by the whole population and selection would be more efficient between genotypes rather than between sub-groups. However, the negative Fis values indicate that individuals accounted for a large proportion of the total variance due to the presence of heterozygotes that could be useful in future selection programs. This could due to high heterozygosity values estimated for the whole germplasm underpinned by mutants and elite lines that have undergone artificial selection, and landraces that may be exhibiting segregation. Individual selection will enhance genetic advance compared to selection within a sub-group.

The phenotypic and genotypic distance matrices exhibited low and non-significant correlation, which confirm that phenotypic and genotypic matrices were independent but complementary. The discordance between phenotypic and genotypic matrices is partly attributed to the significant environmental effect on the variable expression of the assessed phenotypic traits. Phenotypic performance is the result of the genotype, environment and genotype-byenvironment interaction effects [46]. In addition, the inconsistences between genotypic and phenotypic matrices could be due to the fact that genotyping may be able to capture subtle genetic mutations across the whole genome that may not be expressed phenotypically. Other studies reported inconsistences between phenotypic and genotypic matrices in common beans (Phaseolus spp) [47]), yam (Dioscorea spp) [48] and Brassica spp [48]. Due to the expected discord between genotypic and phenotypic matrices, the use of a joint matrix derived from 
combined phenotypic and genotypic matrices has been recommended to increase precision [49; 50]. The strong correlations exhibited by phenotypic and genotypic matrices each with the joint matrix show that each were derivative of the joint matrix and can be used for increased precision as they do not overlap. An increase of more than $150 \%$ in precision was reported while calculating dissimilarity distances using a joint matrix compared to the phenotypic matrix [51].

\section{CONCLUSIONS}

Phenotypic analysis using qualitative and quantitative traits and genotyping using high density SNP markers revealed the presence of significant variation among 100 cowpea germplasm collections of southern Africa. Trait association analysis revealed significant correlation between NPP, NSP, PDL and GYD that could allow direct selection to improve grain yield. The SNP markers used in the study were able to deduce genetic variation among the tested cowpea populations. The largest proportion of variation was attributable to individual genotype differences that is essential for improving grain yield by crossing lines from different divergent populations. Test genotypes were classified in to four genetic groups irrespective of source of collection allowing selection for subsequent cross combinations to develop breeding populations for cultivar development. Genotypes Bubebe, CP411, CP421, CP645, Chimponogo and MS1-8-1-4 were identified being the most genetically divergent and high yielding making them ideal parental lines for breeding. This study provided a baseline genetic profile and identified promising cowpea genetic resources for effective breeding and systematic conservation.

\section{Plant materials}

The study evaluated 90 cowpea genotypes acquired from different sources (Supplementary Table 1). The germplasm included 61 elites lines from Malawi, International Institute for Tropical Agriculture (IITA), Nigeria, The National Gene Bank of Zambia and the University of Zambia, 15 landraces collected from smallholder farmers in Zambia and 14 mutant lines, which were derived from three parental lines; Lutembwe, Bubebe and Msandile. The accessions from IITA and the released cultivars were used as standard checks. 


\section{Phenotyping}

\section{Description of the study sites}

The 100 genotypes were field evaluated during the 2017/2018 main crop season at the following two sites: the Seed Control and Certification Institute (SCCI) in Chilanga and Golden Valley Agricultural Research Trust (GART) in Chisamba/Zambia. The SCCI site is situated at a latitude of $15^{\circ} 32^{\prime} \mathrm{S}$ and a longitude of $28^{\circ} 11^{\prime} \mathrm{E}$ with an altitude of 1206 meters above sea level. The total mean annual rainfall at the SSCI site is $1092 \mathrm{~mm}$, while the mean daily minimum and maximum temperatures were $12^{\circ} \mathrm{C}$ and $26^{\circ} \mathrm{C}$, respectively. The GART site is situated at a latitude of $14^{\circ} 96^{\prime} \mathrm{S}$ and a longitude of $28^{\circ} 10^{\prime} \mathrm{E}$ and an altitude of 1103 meters above sea level. The GART site receives a total mean annual rainfall of $884 \mathrm{~mm}$ with mean daily minimum and maximum temperatures of $10^{\circ} \mathrm{C}$ and $30^{\circ} \mathrm{C}$, respectively. The soils at both sites are classified as Haplustalf clays with $\mathrm{pH}$ of 5.8 and 5.2 at SCCI and GART, respectively [52].

\section{Trial design, field planting and management, and data collection}

The experiments were laid out in a $10 \times 10$ alpha lattice design with two replications. Each genotype was sown in a plot with two rows of $5 \mathrm{~m}$ long. The plot area was $3.75 \mathrm{~m}^{2}$. The interrow and intra-row spacings were 75 and $45 \mathrm{~cm}$, respectively. Two seeds were sown per station at a depth of $2 \mathrm{~cm}$ and later thinned to one plant two weeks after emergence. Basal fertiliser $(\mathrm{N}$ : P: K), containing $20 \%$ nitrogen, $10 \%$ phosphorus and $20 \%$ potassium, was applied at a rate of $200 \mathrm{~kg} \mathrm{ha}^{-1}$ prior to planting. All other agronomic practices for cowpea production were followed as recommended for Zambia [52]. The crops were grown under rain-fed conditions and both sites received an annual rainfall of $850 \mathrm{~mm}$ during the study.

\section{Data collection}

Data was collected from six qualitative and eight quantitative traits following the descriptors of the [15] and [54]. The list of traits and details of data collection and units are provided in Table 1. Grain yield was determined in $\mathrm{kg} \mathrm{ha}^{-1}$ based on the following formula:

$\frac{\text { plot weight }}{\text { plot area }} \times \frac{100-14}{100-m c} \times 10,000$ where; mc is moisture content measured at harvesting, $14 \%$ is standard constant moisture content for legumes [54] and 10,000 is a conversion factor for a hectare. 
Table 1. Qualitative and quantitative traits of cowpea assessed during the study.

\begin{tabular}{|c|c|c|c|}
\hline No & Trait & Abbreviation & Trait description \\
\hline \multicolumn{4}{|c|}{ Qualitative traits } \\
\hline 1 & Flower colour & FLC & Flower colour intensity: violet- 1 , yellow -2 , white- 3 \\
\hline 2 & Leaf green colour & LGC & Colour intensity: light-1, medium -2, dark- 3 \\
\hline 3 & Growth pattern & GTH & Type 1 - determinant, type 2 - indeterminate, type 3 - creeping \\
\hline 4 & Pod colour & PDC & Pod colour intensity; light green-1, deep green -2 , purple- 3 \\
\hline 5 & Seed coat colour & STC & $\begin{array}{l}\text { Primary colour intensity of the seed coat; reddish- brown }-1 \text {, white }-2 \text {, } \\
\text { purplish- brown }-3 \text {, brown }-4 \text {, black }-5 \text {, }\end{array}$ \\
\hline 6 & Leaf size & LFS & Size of the most tip leaf ; small -1 , medium -2 , big -3 \\
\hline \multicolumn{4}{|c|}{ Quantitative traits } \\
\hline 1 & $\begin{array}{l}\text { Days to } 50 \% \\
\text { flowering }\end{array}$ & DTF & $\begin{array}{l}\text { The number of days from sowing until 50\% of the plants in a plot have } \\
\text { visible flowers }\end{array}$ \\
\hline 2 & $\begin{array}{l}\text { Days to } 90 \% \\
\text { maturity }\end{array}$ & DTM & $\begin{array}{l}\text { Days from date of sowing to the date when } 90 \% \text { of pods in a plot turn } \\
\text { yellowish brown }\end{array}$ \\
\hline 3 & $\begin{array}{l}\text { Number of pods } \\
\text { per plant }\end{array}$ & NPP & $\begin{array}{l}\text { Mean number of mature pods from } 10 \text { randomly selected and tagged } \\
\text { plants in a plot }\end{array}$ \\
\hline 4 & Pod length & PDL & Mean length of 10 mature pods from randomly selected and tagged plants \\
\hline 5 & $\begin{array}{l}\text { Number of seeds } \\
\text { per pod }\end{array}$ & NSP & $\begin{array}{l}\text { Mean weight of seed from mature pods of } 10 \text { randomly selected and } \\
\text { tagged plants }\end{array}$ \\
\hline 6 & Seed size & SDS & Mean length of 10 randomly selected seed measured in millimetres \\
\hline 7 & $\begin{array}{l}\text { Hundred seed } \\
\text { weight }\end{array}$ & HSW & $\begin{array}{l}\text { Weight of one hundred randomly selected seeds of a genotype measured } \\
\text { in grams }\end{array}$ \\
\hline 8 & Grain yield & GYD & $\begin{array}{l}\text { The average grain yield per plot and converted into } \mathrm{kg} \mathrm{ha}^{-1} \text { using the } \\
\text { formula given above. }\end{array}$ \\
\hline
\end{tabular}

\section{Data analysis}

The frequency of test genotypes displaying the assessed qualitative traits were summarised and statistical significant tests conducted using the cross tabulation procedure with the Statistical Package for the Social Sciences (SPSS) version 24 [55]. The quantitative data was subjected to analysis of variance (ANOVA) using the alpha-lattice procedure in GenStat ${ }^{\circledR}$ version 18 [56]. A combined analysis of variance was conducted after detecting significant differences among tested genotypes in each location. The following linear model was used for the combined analysis of variance: $\mathrm{Bijk}=\mu+\mathrm{Gi}+\mathrm{Ej}+\mathrm{Gi} * \mathrm{Ej}+\mathrm{Ei}(\mathrm{rk})(\mathrm{b})+\varepsilon i j \mathrm{k}$, where; $\beta \mathrm{ijk}=$ observed response; $\mu=$ grand mean $\mathrm{Gi}=$ the effect of $\mathrm{i}^{\text {th }}$ genotype; $\mathrm{E} \mathrm{j}=$ the effect of $\mathrm{j}^{\text {th }}$ location, $\mathrm{Gi}^{*} \mathrm{Ej}=$ the genotype $\mathrm{x}$ location interaction effect; $\mathrm{Ej}(\mathrm{rk})(\mathrm{b})=$ error associated with $\mathrm{k}^{\text {th }}$ replication in blocks in the $\mathrm{j}^{\text {th }}$ location and $\varepsilon i j \mathrm{k}=$ experimental error. The blocks within 
replications were considered as random factor, while genotypes and locations were fixed factors. Trait means of test genotypes were separated using the Fischers Unprotected LSD at $\mathrm{p} \leq 0.05$ significance level. Genotypic, genotype by location interaction and phenotypic variances were computed from the excepted mean squares of the analysis of variance as follows; $\left.\sigma^{2} g\right)=\frac{\mathrm{msg}-\mathrm{mse}}{\mathrm{lr}} ; \sigma^{2} g l=\frac{\mathrm{msgl}-\mathrm{mse}}{\mathrm{r}} ; \sigma^{2} \mathrm{p}=\sigma^{2} g+\sigma^{2} \mathrm{e}+\sigma^{2} g 1$, where; $\sigma^{2} g=$ genotypic variance, $\sigma^{2} g l=$ genotype by location interaction variance, $\sigma^{2} p=$ phenotypic variance, $\mathrm{msg}=$ mean square of genotype, mse $=$ mean square of error, $1=$ number of location and $r=$ number of replication. Variances below zero were adjusted to zero according to [57]. Heritability in broad sense $\left(\mathrm{H}^{2}\right)$ was computed according to [58]; $\mathrm{H}^{2}=\frac{\sigma 2 g}{\sigma 2 p} x 100$ where; $\sigma^{2} g$ is genotypic variance and $\sigma^{2} p$ is phenotypic variance. Heritability was categorized as low (0-0.30), moderate $(0.30-0.60)$ and high (>0.60) following [59]. A covariance analysis was performed to calculate coefficient of variations. The genotypic coefficient of variation (GCV) and phenotypic coefficient of variation (PCV) expressed in percent were computed as described by [60] as follows: $\mathrm{GCV}=\left(\frac{\sqrt{\sigma^{2}} g}{\bar{\chi}}\right) \times 100 ; \mathrm{PCV}=\left(\frac{\sqrt{\sigma^{2}} p}{\bar{\chi}}\right) \times 100$, were $\sigma^{2} g=$ genotypic variance, $\sigma^{2} \mathrm{p}=$ phenotypic variance, $\bar{\chi}=$ grand mean. Genetic advance was calculated following [61] as follows: $\mathrm{GA}=(k)(\sigma \mathrm{p})\left(h^{2}\right)$, where, $\mathrm{GA}=$ Genetic advance; $k=$ selection differential at $5 \%$ selection intensity; $\sigma \mathrm{p}=$ phenotypic standard deviation; $h^{2}=$ broad sense heritability; Genetic advance as a per cent of mean (GAM) was computed following [62]: GAM $=\left[\frac{\mathrm{GA}}{\bar{x}}\right] x 100$, where, GA $(\%)=$ Genetic advance as a per cent of mean; GA= Genetic advance; $\bar{\chi}=$ Grand mean. Genetic advance as a per cent of mean was classified and rated based on the scales given by [63] as low $(<10 \%)$, moderate $(10-20 \%)$ and high $(>20 \%)$. The magnitude of traits relationship was determined using Pearson's correlation coefficients ( $r$ ) using the SPSS version 24 [55]. Principal component analysis (PCA) was performed using the same software to examine the number principal components and trait associations. The principal components (PCs) with Eigen-values $\geq 1.0$ were considered to explain the variation in phenotypic traits among the genotypes. PCA biplots were constructed in GenStat [56] to depict the relationships among the studied genotypes and traits.

\section{Genotyping}




\section{DNA isolation and genotyping}

Ten seeds of each cowpea genotype were planted in a plastic pot. The seedlings were allowed to grow to the three-leaf stage before fresh leaves were harvested for DNA extraction. Leaves were sampled from each genotype for DNA extraction. Fifty milligrams of total genomic DNA was extracted from the well-developed trifoliate leaves with the NucleoSpin plant II kit (Macherrey- Nagel, Duren, Germany) using the Lysis Buffer 1 (based on the CTAB method) according to the manufacturer's procedures. The DNA concentration of each sample was measured using a NanoDrop 1000 (Invitrogen, California, USA). For verifying DNA integrity, $2 \mu \mathrm{L}$ of DNA were subjected to gel electrophoresis on $1.0 \%(\mathrm{w} / \mathrm{v})$ agarose gel, stained with ethidium bromide. Subsequently, $40 \mu \mathrm{L}$ of a $50 \mathrm{ng} / \mu \mathrm{L}$ DNA of each sample were genotyped with Illumina Cowpea iSelect Consortium Array using Diversity Arrays Technology (DArT) markers. In total, 94 cowpea genotypes were genotyped by the genotyping by sequencing (GBS) technology as described by [64] with 20,000 DArT markers. The markers were integrated into a linkage map by inferring marker order position from the consensus Dart map. Genotyping of the materials was carried out at the Biosciences eastern and central AfricaInternational Livestock Research Institute (BecA- ILRI) in Kenya.

\section{Data analyses}

\section{SNP filtering}

For quality control, DArTseq SNP derived markers were filtered to remove bad SNPs and genotypes using the software's PLINK 1.9 in MS window and R statistical package. Markers and genotypes with $>20 \%$ missing data were eliminated. Rare SNPs with $<5 \%$ minor allele frequencies were also pruned from the data. Only 14,116 informative SNP markers and 90 genotypes were used for analysis after removal of 4240 SNPs and four genotypes. The four genotypes, CP1, CP2, CP479, and CP2223 were removed due to extreme heterozygosity $(<90 \%)$, duplication or high levels of missing data $(>20 \%)$. The chromosomal coverage of the 14,116 SNPs was presented in Supplementary Figure 3.

\section{Population structure and genetic diversity analysis}

The Bayesian clustering method was used for infering the population structure of the germplasm using the STRUCTURE version 2.3 software [65]. The STRUCTURE settings were set at a burn-in period of 5000 and 5000 Monte Carlo Markov Chain (MCMC) iterations with an admixture model to deduce the number of clusters using $\mathrm{K}$ values between 1 and 10 . The best K- value for estimating a suitable population size was identified by the Evanno method in the online based Structure Harvester program [66]. After estimating the best K, a new run using a burn-in period of 100,000 and100, $000 \mathrm{MCMC}$ was performed to assign accessions to 
sub-populations. The accessions with a membership probability lower than 0.80 of a subpopulation were assigned to an admixture group. The genetic structure was further assessed using a Neighbour Joining tree method [67]. Principal component analysis was conducted in TASSEL v.5 [68] using the 14,116 SNPs and plotted using TIBCO spotfire 6.5.0. A dendogram was generated using hierarchical clustering method [69]. The expected heterozygosity (He) and polymorphism information content (PIC) were calculated using [70].

\section{Joint analysis of phenotypic and genotypic data}

A joint analysis based on a combination of phenotypic and genotypic dissimilarity matrices was conducted. A Gower's distance matrix was generated from the phenotypic data while the genotype dissimilarity matrix was computed based on Jaccard's coefficient. The correlations among the phenotypic, genotypic and joint dissimilarity matrices were compared using the Mantel's test with 999 permutations [71] using the package "clusters" and the Daisy procedure [72]. The dissimilarity matrices were used to generate hierarchical clusters in the package "cluster" in R software [72] and compared using the tanglegram function in "dendextend" package in R software [73].

\section{Ethics approval and consent to participate}

Not applicable.

\section{Consent for publication}

Not applicable

\section{Availability of data and materials}

All data generated or analysed during this study are included in this published article and its supplementary information files.

\section{Competing interests}

The authors declare that they have no competing interests.

\section{Funding}

The Alliance for a Green Revolution in Africa (AGRA) funded this research through the African Centre for Crop Improvement (ACCI). The funding bodies had no role in study design, data collection or data analysis.

\section{Authors' contributions}

NN: conceptualized, conducted experiments and data collection, data analysis, data interpretation and writing of initial draft

HS: conceptualized, sourced funding, provided superivision, revised the initial manuscript ML: conceptualized, sourced funding, provided superivision, revised the initial manuscript 
AS: data analysis, intepretation of results, revised the initial maunscript

IM: data analysis, intepretation of results, revised the initial maunscript

\section{Acknowledgements}

The Alliance for a Green Revolution in Africa (AGRA) is sincerily acknowldeged for funding this research through the African Centre for Crop Improvement (ACCI). Thanks are due to the Seed Control and Certification Institute (SCCI) and Zambia Agricultural Research Institute (ZARI) for the overall research support. Chitedze Agricultural Research Station, Malawi, National Gene Bank, small-holder farmers (Zambia) and University of Zambia are thanked for sharing the cowpea garmplasm used in this study.

\section{Author details}

Nelia Nkhoma, is a PhD student in Plant Breeding in the African Centre for Crop Improvement (ACCI) at the University of KwaZulu-Natal.

Professor Hussein Shimelis is Crop Scientist and Professor in Plant Breeding and the Chair of Crop Science. He is also Deputy Director of the African Centre for Crop Improvement, University of KwaZulu-Natal.

Professor Mark D. Laing, Plant Pathologist and Director of the African Centre for Crop Improvement, University of KwaZulu-Natal.

Admire Shayanawako (PhD), Crop Scientist specialized in Plant Breeding and a Post-Doctoral fellow in the African Centre for Crop Improvement.

Isack Mathew (PhD), Crop Scientist specialized in Plant Breeding and a Post-Doctoral fellow in the African Centre for Crop Improvement.

\section{REFERENCES}

1. Enyiukwu D, Amadioha A, Ononuju C. Nutritional Significance of Cowpea Leaves for Human Consumption. Greener Trends in Food Science and Nutrition. 2018; (1)1- 10.

2. Kumar K, Chandra S, Samsher NC, Singh J, Kumar M. Functional Properties of Food Commodities (Wheat, Kidney Bean, Cowpea, Turnip, Cauliflower) Flours. International Journal for Crop Science. 2017; 5: 1199-1202.

3. Boukar, O, Massawe F, Maranaka S, Franco J. Evaluation of Cowpea Germplasm Lines for Protein and Mineral Concentrations in Grains. Plant Genetic Resource. 2019; (4) 515-522.

4. Silva A. Cowpea. A Strategic Legume Species for Food Security and Health. Legume Seed Nutraceutical Research Journal. 2018; 10: 79- 86. 
5. Meena H, Krishna KR, Singh B. Character associations between seed yield and its components traits in cowpea [(Vigna unguiculata (L.) Walp.]. Indian Journal of Agricultural Research. 2015; 49 (6):567- 570.

6. Food Agriculture Organisation of United Nations (FAO), Rome. FAOSTAT Online Statistical Services: Crop Production Data. 2017. Available at http//www.fao.org/faostat/en/\#data. Accessed on 20 October 2018.

7. Singh BB, Ajeigbe HA, Tarawali SA, Fernandez-Rivera S, Abubakar M. Improving the Production and Utilization of Cowpea as Food and Fodder. Field Crops Research. 2003; 84(1-2): 169-177.

8. Horn L, Shimelis H, Laing M. Participatory Appraisal of Production Constraints, Preferred Traits and Farming Systems of Cowpea in Northern Namibia: Implications for Breeding. Legume Research. 2015; 38: 691-700.

9. Molosiwa OO, Chiyapo G, Joshuah M, Stephen MC. Phenotypic Variation in Cowpea (Vigna unguiculata [L.] Walp.) Germplasm Collection from Botswana. International Journal of Biodiversity and Conservation. 2016; 8 (7):153-163.

10. Gerrano AS, Jansen Van Rensburg WS, Adebola P. Nutritional Composition of Immature Pods in Selected Cowpea [Vigna unguiculata (L.) Walp] Genotypes in South Africa. Australian Journal of Crop Science. 2017; 11 (02): 134- 141,

11. Ng NO, Marechal R. Cowpea Taxonomy, Origin and Germplasm. Scientific Research. 1985; 11- 21.

12. Landqvist S. Southern African Development Community (SADC) Plant Genetic Resources Centre (SPGRC) in Zambia urge all World's Gene Banks to use The Seed Vault. 2019. www.seedvault.no>news >. Accessed on 12 April 2020.

13. Villa TCC, Maxted N, Scholten M, Ford-Lloyd, B. Defining and Identifying Crop Landraces. Plant Genetic Resources. 2005; 3(3): 373- 387.

14. Stoilova T, Pereira G. Assessment of the Genetic Diversity in a Germplasm Collection of Cowpea (Vigna unguiculata (L.) Walp) Using Morphological Traits. African Journal of Agricultural Research. 2013; 8 (2): 208-215.

15. IBPGR (International Board for Plant Genetic Resources) Descriptors for Cowpea, Rome, Italy. 1983.

16. Xiong H, Shi A, Mou B, Qin J, Motes D, Lu W, Ma J, Weng Y, Yang W, Wu D. Genetic Diversity and Population of Cowpea (Vigna Unguiculata (L.) Walp) Plos One. 2016; 11 (8): $1-5$.

17. Carvalho M, Lino- Neto T, Rosa E, Carnide V. Cowpea: A Legume Crop for a Challenging Environment. Science of Food and Agriculture. 2017; 97 (13): 4273- 4284.

18. Chen H, Chen H, Hu L, Wang L, Wang S, Wang M, Chang X. Genetic Diversity and Population Structure Analysis of Accessions in the Chinese Cowpea (Vigna unguiculata (L.) Walp) Germplasm Collection. The Crop Journal. 2017; 5 (5): 363372.

19. Gupta PK, Rustgi S, Mir RR. Array-Based High-Throughput DNA Markers for Crop Improvement. Heredity. 2008; 101: 5-18

20. Steemers FJ, Chang WH, Lee G, Barker DL, and Shear R. Whole Genome Genotyping with the Single-Base Extension Assay. Natural Methods. 2006; 3: 31-33.

21. Santos A, Ceccon G, Rodriques EV, Teodoro PE, Makimo PA, Alves VB, Silva J, Correa AM, Alvares RCF, Torres FE. Adaptability and Stability of Cowpea Genotypes 
to Brazilian Midwest. African Journal of Agriculture Research. 2015; 10(40): 39013908.

22. Hassen MB, Bartholome J, Yale G, Cao T, Ahmadi N. Genomic Prediction Accounting for Genotype by Environment Interaction offers an Effective Framework for Breeding Simultaneously for Adoption to an Abiotic Stress and Performance under cropping conditions in Rice. G3; Genes, Genomes, Genetics. 2018; 8(7): 2319 - 2332.

23. Akter A,. Hasan MJ, Kulsum M, Rahman M, Paul A, Lipi L, Akter S. Genotype x Environment Interaction and Yield Stability Analysis in Hybrid rice (Oryza Sativa L.) by AMMI biplot. Bangladesh Rice Journal. 2015; 19(2): 83- 90.

24. Pittelkow CM, Liang X, Linquist BA, van Groenigen KJ, Lee J, Lundy ME, van Kessel C. Productivity Limits and Potentials of the Principles of Conservation Agriculture. Nature. 2015; 517 (7534): 1-6.

25. Sánchez B, Rasmussen A, Porter JR. Temperatures and the Growth and Development of Maize and Rice: A Review. Global Change Biology. 2014; 20(2) 408-417.

26. Mukendi R, Kayenga AL, Babay LL, Bugeme DM, Kalony AM, Munyuli, TM. Genotype- Environment Interactions and Yield Stability of Cowpea (Vigna unguiculata L. Walp) in Lomami Province, Central part of Democratic Republic of Congo. International Journal of Sustainable Agricultural Research. 2019; 6 (1): 33- 46.

27. Khadhem F, Baktash F. AMMI Analysis of Adaptability and Yield Stability of Promising Lines of Bread Wheat (Triticum aestavum L.). The Iraqi Journal of Agricultural Science. 2016; 47(7): 35-43.

28. Darai R, Sarker A, Sah RP, Pokhrel K, Chaudhary R. AMMI Biplot Analysis for Genotype x Environment Interaction on Yield Trait of High Fe Content Lentil Genotypes in Terai and Mid-hill Environment of Nepal. Annals of Agricultural \& Crop Sciences. 2017; 2(1): 1028-1032.

29. Shavrukov A, Kurishbayer S, Jatayer V, Shvidehenko L, Zotova F, Koekemoer S, de Groot K, Soole K, Langridge P. Early Flowering as a Drought Escape Mechanism in Plants: How can it Aid Wheat Production? Frontiers in Plant Science. 2017; 8: 1950.

30. Nkoana DK, Gerrano AS, Gwata ET. Agronomic Performance and Genetic Variability of Cowpea (Vigna unguiculata (L.) Walp) Accessions. Legume Research. 2019; 42 (6) 757- 762.

31. Aliyu OM, Makinde BO. Phenotypic Analysis of Seed Yield and Yield Components in Cowpea (Vigna unguiculata L., Walp). Plant Breeding and Biotechnology. 2016; 4: 252- 261.

32. Mashilo J, Shimelis H, Odindo A. Correlation and path coefficient analyses of qualitative and quantitative traits in selected bottle gourd landraces. Acta Agriculturae Scandinavica, Section B-Soil \& Plant Science. 2016; 66(7):558-69.

33. Herniter IA, Jia Z, Kusi F. Marker Preference for Cowpea (Vigna unguiculata L. Walp). Dry Grain in Ghana. African Journal of Agricultural Research. 2019; 14 (22) 928-934.

34. Herniter IA, Munoz-Amatriain M, Lo S, Guo Y, Close T. Identification of Candidate Genes Controlling Black Seed Coat and Pod Tip Colour in Cowpea (Vigna unguiculata L. Walp).G3. Genes. Genomes. Genetics. 2018; 8 (10): 3347- 3355.

35. Hall AE. Phenotyping Cowpea for Adaptation to Drought. Frontiers in Physiology. Plant Physiology. 2012; 3:155 
36. da Silva MA, Lima PS, de Oliveira VR, de Sousa RP, Barbosa PI.. Intercropping Maize and Cowpea Cultivars: I: Green-grain Yield. Rovista Ciencia Agronomica 2020; 51 (1): $1-10$.

37. Kumar K, Chandra S, Samsher NC, Singh J, Kumar M. Functional properties of food commodities (wheat, kidney bean, cowpea, turnip, cauliflower) flours. International Journal for Crop Science. 2017; 5: 1199-1202.

38. Pathak AR, Naik, MR, Joshi HK. Heterosis, Inbreeding and Heritability for Grain Yield and Yield Components in Cowpea. Electronic Journal of Plant Breeding. 2017; 8 (1) 72- 77.

39. Sharma M, Sharma PP, Upadhy B, Bairwa HL, Meghawal DR. Character association and Path Analysis in Cowpea [Vigna unguiculata (L.) Walp] Germplasm Lines. International Journal for Curriculum Microbiological Application Science. 2017; 6 (6): 786-765.

40. Arora RN, Kumar K, Manav K. Principal Component Analysis in Kabuli Chickpea (Cicer arietinum L.). International Journal of Chemical Studies. 2018; 6(2) 2767-2768.

41. Walle T, Mekbib F, Amsalu B, Gedil M. Genetic Diversity of Ethiopian Cowpea (Vigna unguiculata L. Walp) Genotypes using Multivariate Analysis. Ethiopian Journal of Agricultural Sciences. 2019; 29 (3): 89- 104.

42. Araújo LB, Pinheiro MD, Fiege LB, Bertini CH, Dovale JC. Agronomic Potential And Genetic Diversity Of Landraces Of Cowpea Of The State Of Ceará. Revista Caatinga. 2019; 32(3):698-708.

43. Huang R, Chu QH, Lu GH, Wang YQ. Comparative studies on population genetic structure of two closely related selfing and outcrossing Zingiber species in Hainan Island. Scientific reports. 2019; 9(1):1-1.

44. Viana VE, Pegoraro C, Busanello C, de Oliveira AC. Mutagenesis in rice: the basis for breeding a new super plant. Frontiers in Plant Science. 2019; 10.

45. Good-Avila SV, Mena-Alí JI, Stephenson AG. Genetic and environmental causes and evolutionary consequences of variations in self-fertility in self incompatible species. In Self-incompatibility in flowering plants 2008. Springer, Berlin, Heidelberg. pp. 33-51.

46. Singh SP, Nodari R, Gepts P. Genetic diversity in cultivated common bean: I. Allozymes. Crop Science. 1991; 31(1):19-23.

47. Guidoti DT, Gonela A, Vidigal MC, Conrado TV, Romani I. Interrelationship between morphological, agronomic and molecular characteristics in the analysis of common bean genetic diversity. Acta Scientiarum. Agronomy. 2018; 40.

48. Agre P, Asibe F, Darkwa K, Edemodu A, Bauchet G, Asiedu R, Adebola P, Asfaw A. Phenotypic and molecular assessment of genetic structure and diversity in a panel of winged yam (Dioscorea alata) clones and cultivars. Scientific reports. 2019; 9(1):1-1.

49. Sartie A, Asiedu R, Franco J. Genetic and phenotypic diversity in a germplasm working collection of cultivated tropical yams (Dioscorea spp.). Genetic Resources and Crop Evolution. 2012; 59(8):1753-65.

50. Singh N, Vasudev S, Kumar Yadava D, Kumar S, Naresh S, Ramachandra Bhat S, Vinod Prabhu K. Assessment of genetic diversity in Brassica juncea Brassicaceae genotypes using phenotypic differences and SSR markers. Revista de biología tropical. 2013; 61(4):1919-34.

51. Alves AA, Bhering LL, Rosado TB, Laviola BG, Formighieri EF, Cruz CD. Joint analysis of phenotypic and molecular diversity provides new insights on the genetic 
variability of the Brazilian physic nut germplasm bank. Genetics and Molecular Biology. 2013; 36(3):371-81.

52. Sichinga S. Priorities for the Management of Soils in Zambia. Ministry of Agriculture and Livestock. Food and Agriculture Organisation (FAO). National Agriculture Information Publications (Zambia). 2013; 8: 4- 9.

53. Muliokela SW. Zambia Seed Technology Handbook. Ministry of Agriculture, Food and Fisheries. 1997; 394.

54. Parker A, Namuth-Covert D. Guidelines for the Conduct of Tests for Distinctness, Uniformity and Stability. International Union for the Protection of New Varieties of Plants (UPOV). Geneva. 2017.

55. Statistical Package for the Social Sciences (SPSS). Version 24. 2017

56. Payne R, Harding S, Murray D, Soutar D, Baird D, Glaser A, Channing I, Welham S, Gilmour A, Thompson R, Webster R. The Guide to GenStat Release 12 VSN International. Hemel Hempstead. 2009.

57. Robinson HF, Comstock RE, Harvey PH. Genetic variances in open pollinated varieties of corn. Genetics. 1955; 40(1):45.

58. Falconer DS, Mackay TC. Introduction to Quantitative Genetics. John Willey and Sons. 1989. p 313-320.

59. Robinson HF, Comstock RE, Harvey PH. Estimates of Heritability and the Degree of Dominance in Corn. Agronomy Journal. 1949; 41(8):353-9.

60. Singh RK, Chaudhary BD. Biometrical Methods in Quantitative Genetic Analysis. Kalyani Publications, New Delhi. 1985.

61. Allard RW. Principles of Plant Breeding. Soil Science. 1961 91(6):414.

62. Souza E, Sorrells ME. Relationship among 70 North American Oat Germplasm 1. Cluster Analysis using Quantitative Characters. Crop Science. 1991; 31: 599- 605.

63. Johnson HW, Robinson HF, Comstock RE. Estimates of Genetic and Environmental Variability in Soybeans. Agronomy Journal. 1955; 47 (7): 314-318.

64. Elshire RJ, Glaubitz J, Poland A, Kawamoto K, Bucler ES, Mitchell SE. A Robust, Simple Genotyping-by- Sequencing in (GBS). Approach for High Diversity Species. Plos One 2011; 6, e19379.

65. Pritchard JK, Stephens M, Donnelly P. Inference of population structure using multilocus genotype data. Genetics. 2000; 155(2): 945-59.

66. Evanno G, Regnaut S, Goudet J. Detecting the number of clusters of individuals using the software STRUCTURE: a simulation study. Molecular ecology. 2005; (8):2611-20.

67. Saitou N, Nei M. The Neighbor-Joining Method: A New Method for Reconstructing Phylogenetic Trees. Molecular Biology Evolution. 1987; 4 (4): 406- 25.

68. Bradbury PJ, Zhang Z, Kroon DE, Casstevens TM, Ramdoss Y, Buckler ES. TASSEL: software for association mapping of complex traits in diverse samples. Bioinformatics. 2007; 23(19):2633-5.

69. Johnson SC. Hierarchical clustering schemes. Psychometrika. 1967; 32(3):241-54.

70. Botstein D, White RL, Skolnick M, Davis RW. Construction of a genetic linkage map in man using restriction fragment length polymorphisms. American Journal of Human Genetics. 1980; 32(3):314.

71. Mantel N. The detection of disease clustering and a generalized regression approach. Cancer research. 1967; 27(2 Part 1):209-20. 
72. Maechler M, Rousseeuw P, Struyf A, Hubert M, Hornik K. Cluster: cluster analysis basics and extensions. R package version. 2012; 1(2):56.

73. Galili T. dendextend: an R package for visualizing, adjusting and comparing trees of hierarchical clustering. Bioinformatics. 2015; 31(22):3718-20. 


\section{Figures}

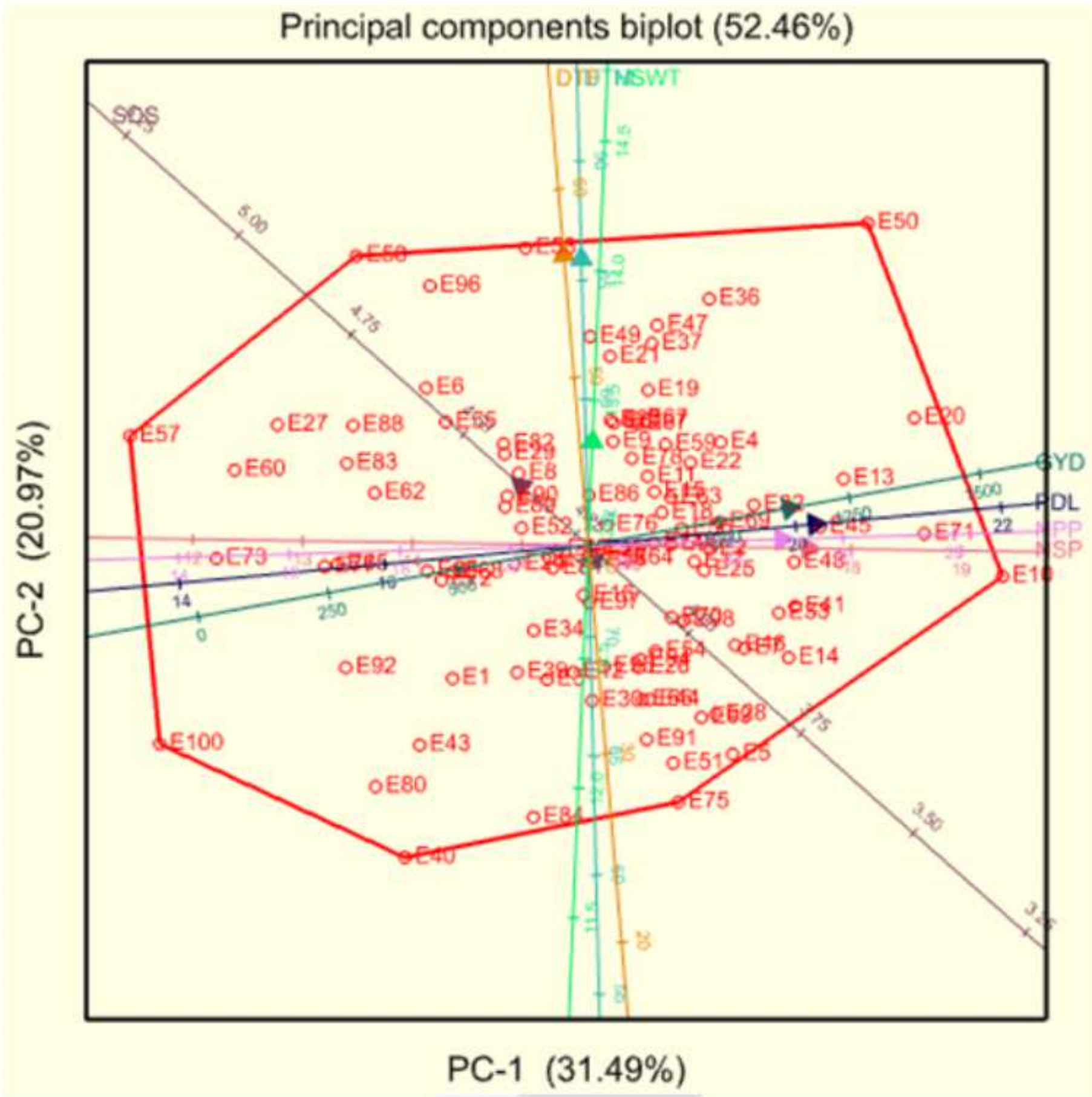

Figure 1

Genotype-trait biplot showing association of eight quantitative traits in 100 genotypes of cowpea assessed in two locations. Note: DTF: days to flowering; DTM: days to maturity; PDL: pod length $(\mathrm{cm})$, NPP: number of pods per plant; NSP: number of seeds per pod, HSW: hundred seed weight (g), GYD: grain yield in kg per hectare PC-1 and PC-2: principal component 1 and principal components 2, respectively 

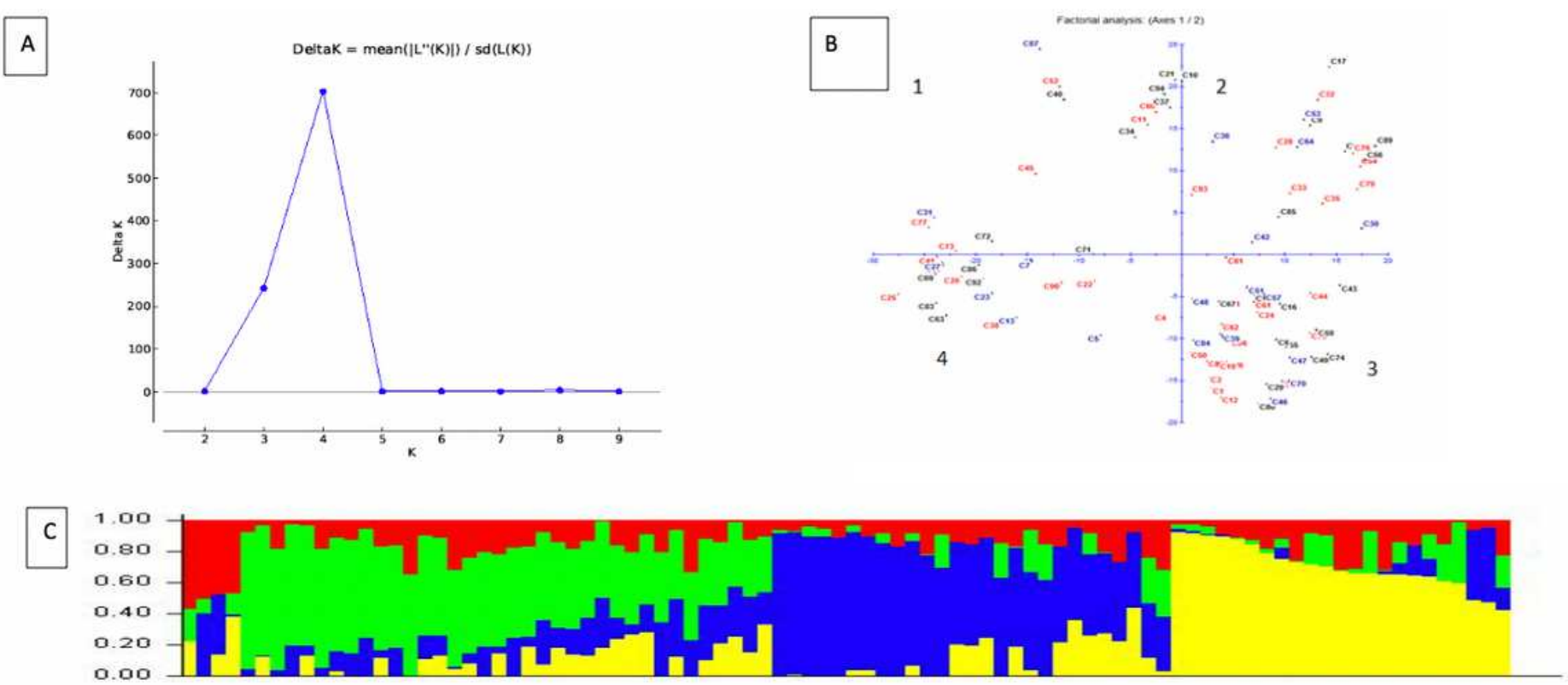

Figure 2

Subpopulation inference among the 90 cowpea accessions based on 14166 SNPs showing (A) likelihood and delta $\mathrm{K}$ values for different number of assumed clusters, (B) principal component analysis clustering of the genotypes and (C) population structure at $\mathrm{K}=4$.

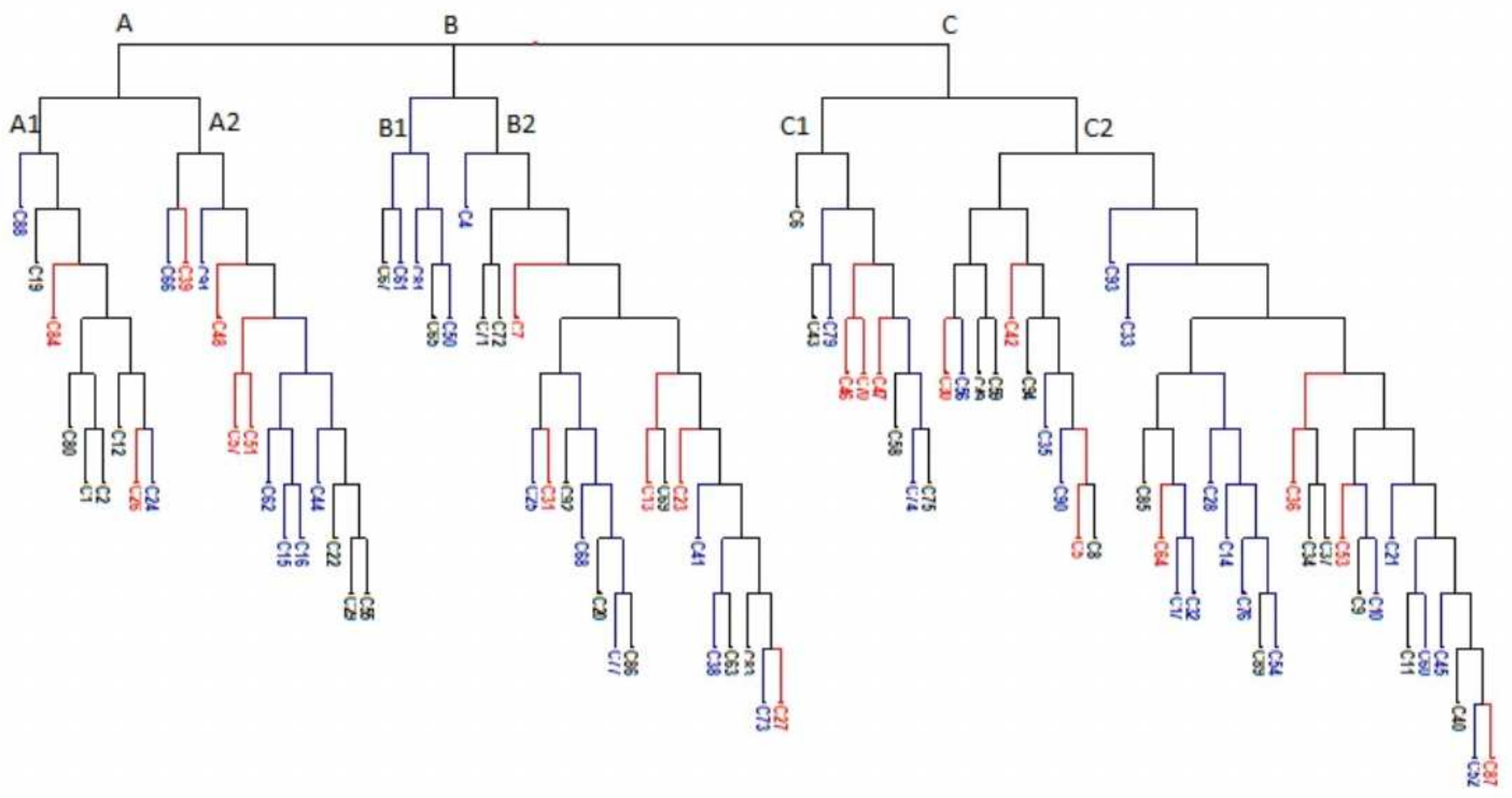

Figure 3 
The neighbour-joining phylogenetic tree showing relatedness among the 100 cowpea genotypes based on 14116 SNP markers

\section{Supplementary Files}

This is a list of supplementary files associated with this preprint. Click to download.

- AdditionalfilesBMCGeneticsGTICD2000135.docx 